Southern Illinois University Edwardsville

SPARK

SIUE Faculty Research, Scholarship, and Creative Activity

10-13-2016

\title{
A Qualitative Metasynthesis of Consultation Process Research: What We Know and Where to Go
}

Daniel Newman

University of Cincinnati, newmand4@ucmail.uc.edu

Elizabeth L.W. McKenney

Southern Illinois University Edwardsville, elmcken@siue.edu

Arlene E. Silva

William James College, arlene_silva@williamjames.edu

Mary Clare

Clare Consulting,mary@clareconsultation.com

Diane Salmon

National Louis University, dsalmon@nl.edu

See next page for additional authors

Follow this and additional works at: http://spark.siue.edu/siue_fac

Part of the Educational Psychology Commons, School Psychology Commons, and the Special Education and Teaching Commons

\section{Recommended Citation}

Newman, Daniel; McKenney, Elizabeth L.W.; Silva, Arlene E.; Clare, Mary; Salmon, Diane; and Jackson, Safiyah, "A Qualitative Metasynthesis of Consultation Process Research: What We Know and Where to Go" (2016). SIUE Faculty Research, Scholarship, and Creative Activity. 55.

http://spark.siue.edu/siue_fac/55

This Article is brought to you for free and open access by SPARK. It has been accepted for inclusion in SIUE Faculty Research, Scholarship, and Creative Activity by an authorized administrator of SPARK. For more information, please contact gpark@siue.edu. 


\section{Authors}

Daniel Newman, Elizabeth L.W. McKenney, Arlene E. Silva, Mary Clare, Diane Salmon, and Safiyah Jackson

\section{Cover Page Footnote}

This is an Accepted Manuscript of an article published by Taylor \& Francis in Journal of Educational and Psychological Consultation on [date of publication], available online: http://dx.doi.org/10.1080/ 10474412.2015.1127164. 
A Qualitative Metasynthesis of Consultation Process Research:

What We Know and Where to Go

\author{
Daniel S. Newman, \\ University of Cincinnati \\ Elizabeth L. W. McKenney, \\ Southern Illinois University Edwardsville \\ Arlene E. Silva, \\ William James College \\ Mary Clare, \\ Clare Consultation, LLC \\ Diane Salmon, \\ National Louis University \\ Safiyah Jackson, \\ National Louis University
}




\begin{abstract}
Qualitative metasynthesis $(\mathrm{QM})$ is a research methodology that permits the meaningful integration and interpretation of qualitative research. This study applies a QM approach combined with constructivist grounded theory methods, bolstered by several features of research credibility, to examine the state of consulteecentered consultation (CCC) and related relational, process-oriented school consultation research. A systematic search and retrieval process including two rounds of appraisal resulted in a final sample of 38 relevant studies from 1995 to 2014. Data analyses included two stages of coding/theme development. Integrated themes suggest a number of considerations regarding consultation implementation including: system-level factors; consultation structure; consultee voice, socialemotional support and learning; ecological orientation and cultural responsiveness; and consultation training. Future research priorities stemming from these themes are identified and elaborated upon, as are future applications for QM in educational research.
\end{abstract}

Keywords: consultee-centered consultation; research synthesis; qualitative metasynthesis; process research 
A Qualitative Metasynthesis of Consultation Process Research:

What We Know and Where to Go

In the introduction to the comprehensive Handbook of Research in School Consultation, Erchul and Sheridan (2014) described the research base supporting school-based consultation as "promising, emerging, and developing" (p. 3). Indeed, a strong body of research suggests the implementation of school-based consultation, more often than not, results in positive outcomes for consultees and clients (Erchul \& Sheridan, 2014). Can the same conclusions be drawn about consultee-centered consultation (CCC), specifically? Furthermore, what evidence exists regarding the various relational processes that are defined as critical to CCC, such as interpersonal communication, relationship building, collaborative problem solving, and cultural responsiveness in consultation (Ingraham, 2000; Lambert, 2004; Meyers, 1973)?

The answers to these questions remain elusive. In a research review of CCC and its predecessor, mental health consultation (MHC), Knotek and Hylander (2014) concluded that establishing a convincing evidence-base for relational processes "has been difficult, if not impossible, to achieve" (p. 158). Yet, over the past two decades, a notable collection of researchers have in fact completed intensive, high quality studies on CCC and related relational consultation processes. To date, no attempt has been made to synthesize empirically the knowledge base now composed by these studies. Such meta-consideration would investigate the credibility, dependability and practicality (Eisner, 1997) of this research base, and assist with establishing a coherent and convincing foundation cataloguing what we know and do not know with regard to practice, training and directions for future research. 
In this study, we have three aims:

1. To gather empirically, for the first time, the current qualitative research on CCC and related relational, process-oriented school consultation research that may have relevance for CCC practice;

2. To apply metasynthesis to this knowledge base to integrate what we know about CCC and related school consultation processes; and

3. To propose an agenda for future research from two perspectives:

a. The efficacy of qualitative research methodology for reflecting relational processes in consultation, and

b. The status of the knowledge base with regard to CCC and relational processes in school consultation.

\section{Foundational Assumption: Interpersonal Interactions are Broadly Relevant to Consultation}

The current study synthesizes (a) research focused on the CCC model as defined in the introduction to this special issue, as well as (b) non-CCC studies that focus a research lens on interpersonal interactions, or processes, such as those at the heart of CCC (defined here to include interpersonal communication, relationship building, collaborative problem solving, and cultural competence in consultation; Ingraham, 2000; Lambert, 2004; Meyers, 1973). For the purposes of researcher reflexivity (Creswell, 2013), we acknowledge an embedded assumption informing this study and shared by all members of the research team: Processes of consultation are not CCC-specific, but are integrative across all consultation models/approaches (Henning-Stout, 1993). For example, research by Newell and 
colleagues that is included in this analysis (Newell, 2010a; Newell, 2010b; Newell, 2012; Newell \& Newell, 2011; Newell, Newell, \& Looser, 2013a; Newell, Newell, \& Looser, 2013b; referenced in Appendix) is focused on behavioral/problem-solving consultation, but results appear to have implications for CCC. In sum, we believe that this study has the potential to contribute to our knowledge of CCC, but also to consultation research and practice more broadly.

\section{Synthesizing Research: Towards Evidence-Based Practice}

Research synthesis is the process of aggregating and integrating a body of research literature in a systematic manner resulting in a coherent, holistic understanding of the topic of interest. Synthesizing knowledge is an essential facet of evidence-based practice (EBP), a movement that proliferated first in the field of medicine, and subsequently in other professional areas, such as psychology and education (Kratochwill, 2007). Indeed, by definition, EBP involves integrating the "best available research" with application of professional skills in action (e.g., see American Psychological Association, 2006).

Meta-analysis is a common methodological approach used to synthesize quantitative data from related studies, thereby providing evidence for particular interventions or programs. The synthesis of qualitative data in a parallel fashion to quantitative meta-analysis has become an increasingly accepted approach to understanding EBP in fields such as health sciences (Rice, 2008; Ma, Roberts, Winfield, \& Furber, 2015; Sandelowski \& Barroso, 2007), and education (Erwin, Brotherson, \& Summers, 2011). As reported by Major and Savin-Baden (2010), over 150 such syntheses have been conducted since the year 2000 . We use the term 
qualitative metasynthesis (QM) to describe the current study, consistent with previous application of the methodology in educational research (e.g., Erwin et al., 2011; Scruggs, Mastropieri, \& McDuffie, 2007).

QM is concerned with achieving higher order theme integration, while respecting individual study integrity (Scruggs et al., 2007). The process is methodologically grounded, rigorous, iterative, and interpretative. It allows researchers to draw conclusions about practice and policy in a way that is relevant to the lived experiences of practitioners and policy makers in addition to researchers (Major \& Savin-Baden, 2010). As described by Erwin et al. (2011) in a discussion about the relevance of QM to EBP in early childhood intervention research:

The contribution that qualitative metasynthesis can make to evidence-based practices does not focus solely on what practices or interventions work or do not work, but rather, it can help in understanding how, when or why ... In this way, evidence-based practices can be viewed through a broader contextual and culturally rich lens (p. 188).

\section{Challenges in Process-Focused Consultation Research}

Prior to reporting on the metasynthesis itself, it is necessary to explore some of the challenges in conducting high quality research on CCC and related consultation processes. Challenges include

1. The wide range of models that explicitly rely on relational processes associated specifically with CCC (e.g., interpersonal communication, 
relationship building, collaborative problem solving, and cultural competence);

2. The lack of technical specificity in defining these processes; and

3. The divergence of appropriate methodological approaches from popular research paradigms - that is, consultation practice is far more interpersonally affected than prevailing research methodologies have so far reflected.

First, CCC is implemented and researched in a variety of forms that are difficult to understand as a coherent whole (Knotek \& Hylander, 2014). For example, some consultation models may be viewed as distinct types of CCC with distinct research bases (e.g., instructional consultation and instructional consultation teams, Rosenfield, Gravois, \& Silva, 2014), and other approaches are relevant to multiple consultation models in addition to being foundational to CCC (e.g., a multicultural school consultation framework, Ingraham, 2000; 2014). Second, unlike models such as behavioral/problem solving consultation, CCC does not have a specific implementation protocol (Knotek \& Sandoval, 2003b), potentially disallowing numeric constructs such as treatment integrity.

A third research challenge is that hypothetico-deductive or probabilistic research (e.g., randomized evaluation studies), the current empirical zeitgeist in psychological research, may not be the most suitable approach to study CCC, or related process-oriented approaches to consultation (Hylander, 2004; Knotek \& Hylander, 2014). CCC and related process orientations to supporting learning and learners have been foundational to school-based consultation practice since its 
inception (Henning-Stout, 1993; Meyers, 1973). It is therefore no coincidence that qualitative research methodologies such as ethnography, grounded theory, and case study have been applied in the study of CCC and related consultation processes to help researchers describe and understand essential relational phenomena of interest (see Table 1).

With respect to school-based consultation research, syntheses commonly cited in support of the overarching effectiveness of school consultation (e.g., Sheridan, Welch, \& Orme, 1996) explicitly exclude process-oriented research from the sample of studies for analysis. For example, Sheridan, Welch, and Orme (1996) excluded from their review of consultation research from 1985 to 1995 those studies with "process-oriented analyses (such as those pertaining to relational or control variables)" (p. 343). Studies focused on MHC or CCC are also implicitly excluded from consultation research syntheses (e.g., Reddy, Barboza-Whitehead, Files and Rubel, 2000) given (a) the defining features of CCC, which are processoriented, and (b) the tendency for qualitative methods to be used in studies of processes, but for such methods to be excluded from meta-analyses.

Given challenges in studying MHC, CCC and associated processes of consultation, process-oriented studies are not only few in number, extant studies are also "far between", or not well connected to each other. The result is "little islands" (Glaser \& Strauss, 1971, p. 181, in describing Grounded Theory) of fragmented or isolated knowledge rather than a clear, comprehensive and integrated evidence base regarding processes of consultation.

\section{Process of Inquiry}


The merits and limitations of QM are described extensively in the literature (e.g., see Major and Savin-Baden, 2010). As summarized by Sandelowski and Barroso (2007), some qualitative researchers object to QM because in their view it (a) conforms too much to mainstream quantitative approaches, and (b) deindividualizes complex studies in a way that may detract from richly documented human experiences. Of further concern is "conceptual drift", the notion that QM means different things to different people, and its implementation may be more or less rigorous from one study to the next, thereby limiting credibility for the approach (Sandelowski \& Barroso, 2007, p. 8). Therefore, a clear description of the process of inquiry for this study is described, enabling future researchers to (a) enhance synthesis credibility by demonstrating the application of rigorous methodological standards (Cooper, 2010) and (b) allow for replication of a QM in the future in the study of school-based consultation, or related areas.

\section{Research Team Composition}

The research team included individuals with a wide range of prior experiences (a school psychology graduate student, and early-, mid-, and late-career school psychology researchers) and perspectives on consultation. One of the researchers (MC) was invited to join the team given her extensive experience as a qualitative researcher in the area of school-based consultation. Three of the team members had no prior experience conducting qualitative research. The diversity of the team members allowed for critical thinking from multiple perspectives to be applied to the study's conceptualization, data collection and analysis and to the integration and interpretation of results. 


\section{QM as a Grounded Theory Methodology}

This study is based in a constructivist worldview (Lincoln \& Guba, 2013) using Grounded Theory (GT) methodology and methods (Charmaz, 2014; Glaser \& Strauss, 1967; Strauss \& Corbin, 1998). GT is a theory-generating empirical tradition that aligns well with the over-arching constructivist framework that informs CCC practices, such as the collaborative co-construction of problems and solutions; it is also a match given the historic and emerging nature of CCC in contemporary schoolbased practice (Knotek \& Hylander, 2014). A constructivist GT approach encourages researcher flexibility and enhances interpretability by focusing on meaning (Charmaz, 2014). In addition, GT relies on rigorous empirical integrity through assessments of credibility and dependability. That is, assessments are conducted throughout GT via methodological hallmarks such as well-defined stages of coding; constant comparisons of data, themes, and categories; and theoretical sampling, or seeking information to refine emerging categories and theories. The research team determined each of these features of GT methodology to be critical to the innovative task of applying QM to study school-based consultation.

\section{Data Collection: Selection Criteria, Search/Retrieval, and Appraisal}

The data collection process included (a) conducting a systematic search and retrieval process to cast a wide net $(n=162)$, and (b) conducting two rounds of appraisal to determine if studies should be included or excluded in the synthesis. The full data collection process is illustrated in Figure 1. Consistent with QM being an iterative process (Major \& Savin-Baden, 2010), a few additional studies were eliminated from the final sample during the coding process because they did not 
meet inclusionary criteria, resulting in 38 studies included in the final analysis (see Table 1 and Appendix). Consistent with systematic GT development, each study was treated as an individual study participant.

Initial identification of studies: Casting a wide net. The QM was focused on CCC and related process-oriented approaches to school-based consultation, as previously defined. Because the first international seminar on CCC was held in 1995, a meeting that redefined CCC for contemporary schools (Lambert, 2004), only studies from 1995 to 2014 were included in the review. The initial search for articles was broadly inclusive, designed to prevent false negative exclusion of research from the sample. Qualitative and mixed methods studies of CCC in schools as well as qualitative and mixed methods studies of processes of consultation in schools were identified for the initial sample via review of each study's title and abstract.

To compile the studies, the research team conducted (a) a hand search of journals related to school psychology and/or consultation (i.e., Consulting Psychology Journal: Practice and Research; Journal of Consulting and Clinical Psychology; Journal of Educational and Psychological Consultation; Journal of School Psychology; Psychology in the Schools; School Psychology Review; School Psychology International; Journal of Applied School Psychology; School Psychology Quarterly), and (b) systematic searches using PsychINFO and ERIC databases. Systematic searches included cross-searching "school consultation" or "consultation" with qualitative research methodologies (i.e., qualitative, ethnography, grounded theory, case study, phenomenology, narrative, mixed methods), and process-oriented 
models of consultation (i.e., consultee-centered consultation; conjoint behavioral consultation; instructional consultation; mental health consultation; multicultural consultation; organizational consultation; process consultation; systems consultation). An author search was also conducted to search for names of authors who appeared more than twice as a first author in studies already identified. When a researcher was unsure whether a study should be included in the sample, the decision was made to include the study in the initial sample with the knowledge that the team would soon engage in further appraisal. The first round of data collection resulted in 162 research studies considered for inclusion in the QM.

Determining the final sample. Once the initial sample of studies was identified, the researchers read each article to winnow the sample, retaining those that were: (a) empirical (case studies that provided an example but did not describe research methods were excluded); (b) inclusive of qualitative data that was interpreted within the study (studies that reported but did not interpret qualitative items from a survey were eliminated); and (c) focused on CCC or relevant interpersonal processes of consultation in schools (studies that reported on perspectives about consultation, but did not include descriptions and analysis of interpersonal consultative interactions, were eliminated). When an individual researcher was unsure of whether a study should be included in the reduced sample, a minimum of three team members reached consensus on inclusion or exclusion through discussion about how the article met or did not meet appraisal criteria. Winnowing down studies continued through the entirety of the QM process, rendering a final sample of 38 studies. 
Although we applied clear appraisal criteria, it is still possible that some articles may have been inadvertently neglected from the final sample (i.e., a false negative) due to errors in individual decision-making prior to team discussion. In fact, the member checking process, described in full detail in a subsequent section of the article, identified at least one false negative (i.e., Truscott, Cosgrove, Meyers, \& Eidle-Barkman, 2000). The QM research team reviewed this article and verified that its content reflected the themes developed through the analysis.

\section{Data Analysis}

The research team engaged in a coding process as developed through constructivist GT research (Charmaz, 2014). First, team members documented each study's research questions, theoretical framework (if specified), research methodology, consultation models (if specified), sample composition in terms of participant numbers and roles, the research context (e.g., school building, IEP or other teaching team, administration), data collection processes, data analysis processes, main findings, and credibility/trustworthiness features. The research team members, as a full team, discussed and agreed upon clear definitions of each of these more descriptive features to ensure accuracy across coders. The first interpretative stage of coding was initial coding. The second interpretive stage of coding was focused coding, or "themeing the data" (Saldaña, 2013). Through both stages of coding, the researchers applied constant comparative methods (Charmaz, 2014; Strauss \& Corbin, 1998), which included comparing data (initial codes) and emerging themes (focused codes) across studies, while also comparing emerging interpretations of meaning across researchers in team debriefing sessions. In 
essence, the team engaged in a process of "translating the studies into one another" by comparing study results and interpretations of similar results from one study to the next (Noblit \& Hare, 1988, p. 28).

Initial coding. The initial coding stage consisted of two phases. For the first phase of initial coding, each of the research team members reviewed and coded four randomly selected articles from the final sample, one of which overlapped with another group member. Consistent with suggestions proposed by Charmaz (2014), initial individual coding was guided by the broad questions: What did the study focus on? How did the researcher(s) do it? What are the findings? Does it seem credible? Next, two subgroups of the researchers met to discuss the coding process. Finally, the full team met to use these initial coding experiences to inform researcher consensus on initial codes. A total of eight articles were coded during phase one of initial coding.

Phase two of initial coding was guided by the codes established at the end of phase one: system challenges; system facilitators or solutions; contextual considerations; cultural responsiveness; family involvement; consultation-specific challenges; consultation-specific facilitators or solutions; training implications; and research implications (see Table 2). The remaining 30 studies were divided across the researchers for coding using this coding taxonomy. Researchers also assigned idiosyncratic secondary codes to capture individual readings of the data.

Inter-coder agreement. During the second phase of initial coding, three randomly selected studies were coded across two or three team members to determine inter-coder agreement, also known as dependability (i.e., to interrogate 
the consistency of code application across researchers). Agreement ranged from $67 \%$ to $93 \%$, with discrepancies primarily related to the same information being coded but in different initial coding categories. For example, content coded as a systems-level facilitator for one researcher was coded as a consultation facilitator by another researcher. In other words, little content differed from one rater to the next. All discrepancies were discussed and 100\% agreement was reached in dyads and triads regarding assigned coding category.

Focused coding. Focused coding is the second major stage of coding in establishing GT, and allows researchers to synthesize and explain larger segments of data than are coded in the initial coding stage (Charmaz, 2014). Although this stage is described as a coding stage, the focus is on extracting themes from the initial coding. The process is intensive, and particularly applicable to the analysis of artifacts such as extant research studies (Saldaña, 2013). To begin the stage, each team member independently compared the data from all studies across each initial code. Next, each team member independently compared the data from all studies across all codes. After all of the research team members completed their independent analyses, these findings were compiled for review by the full research team without discussion. Finally, the first author compiled the analyses and sent them out for feedback from the group. The themes emerging from this integration are described in detail in the Results section of this paper.

\section{Credibility}

Several steps were taken to enhance the credibility, or trustworthiness, of the QM. Credibility features reflect the integrity of qualitative research relative to 
what researchers claim is being measured (i.e., parallel to the concept of validity in traditional quantitative studies; Eisner, 1997). The term trustworthiness is also used in reports of QM to indicate systematic interrogation of the content, concept and methodology to verify an investigation's integrity. To communicate the current study's credibility, researchers agreed on the accuracy of a posteriori dense descriptions of (a) the studies included in the review, including original data from these studies, and (b) the methods applied in the QM. These and additional credibility tests were drawn via audit trail, maintained both individually and collectively by team members. Further extending the rigor of credibility checks, one of the researchers (MC) joined the QM team when the research process was under way to fill the dual roles of research auditor and researcher by reviewing notes on the development of the study, and helping to guide team-based methodological decisions (Schlosser, Dewey, \& Hill, 2012).

Member checking. Finally, the researchers engaged in a member checking process, which included contacting six authors of studies included in the review, and also well known experts on CCC, to provide feedback on: (a) research methodology and methods; (b) how emergent themes fit with their knowledge of CCC and related processes of consultation; (c) how next research priorities fit with their knowledge of CCC and related processes of consultation; and (d) any additional feedback they might have. All six member checkers suggested increasing clarity of inclusionary/exclusionary criteria of studies and processes of team decisionmaking, and the research team responded to this feedback by elaborating on the description of the methods in the narrative. Other areas where member checking is 
reflected in this paper include clarifying themes, as well as their integration; commenting on the research team's decision to combine consultant, consultee, client and researcher reports to establish themes; and adding to next research priorities.

\section{Results and Discussion}

The QM analysis reported here resulted in a descriptive overview of qualitative research on CCC and related relational processes, with five themes emerging from the data. Consistent with robust GT, this metasynthesis provided solid empirical ground for a larger view on relational processes in CCC and across consultation models. These themes reflect a systems perspective illuminating considerations for consultation structure, role relationships, focus, and preparation. Consultation inhibitors and facilitators emerged within each broader theme to reveal two sides of the same thematic coin.

Concurrent with the themes, QM gains illustration as a research methodology well suited to investigating the more qualitative aspects of successful consultation. The resulting themes are inextricable from relevant discussion of next directions for research with regard both to relational consultation processes, and to the improvement and extension of QM as a research approach. Given this circumstance, we offer here a combined summary of results and discussion. In-text citations for themes and subthemes include those studies with the most prominent evidence; please find a summary of all studies supporting each thematic area in Table 3.

\section{The Data Set}


Participants. Participants across the 38 studies in our sample included 186 consultants, 167 identified as school psychology faculty, practicing school psychologists, or school psychology graduate students, and 19 who identified as other professionals/specialists (e.g., occupational therapists, early childhood mental health consultants, reading coaches). Studies that described specific professions of consultees included 141 teachers, five mental health professionals other than school psychologists (i.e., social workers, guidance counselors), and 16 administrators. Fourteen parent consultees participated in one study. A total of 20 consultationbased teams were included in the data. One study did not specify the number of teams, but reported that 134 prereferral team members participated. In other studies, participants included six consultation dyads observed via archived video, 16 early childhood family specialists, five students, and six language interpreters.

Since the unit of analysis for the QM was 38 studies rather than the participants in these studies, data from consultants, consultees, clients and researchers are integrated in the development of themes. Only three studies in the sample (Hazel, Pfaff, Albanes, \& Gallagher, 2014; Lopez, 2000; Meyers, 2002) included client data, such as interviews with students and/or parents.

Settings. Geographic representation of studies included seven studies conducted in the Midwest, six in the Southeast, six in the West, five in the Northeast, and three in the Mid-Atlantic region. Two studies were conducted in Canada (one in Quebec, one unspecified), and one in New Zealand. Eight studies did not specify a location. Twenty-two studies took place in elementary settings. Nine were conducted across multiple grade levels, some spanning an entire district, others 
spanning two service levels (i.e., prekindergarten through elementary). Three studies were specifically conducted within a high school setting. No studies were identified as taking place in a junior high setting, while two studies took place at the secondary level.

Publication trends. Sixteen of 38 studies (42\%) in our sample were published in the Journal of Educational and Psychological Consultation (JEPC), indicating the receptiveness of $J E P C$ to qualitative research on relational processes of consultation. Thirteen studies (34\%) were published between 2010 and 2014, suggesting a promising trend of research proliferation in this area. The only fiveyear span with more articles was 2000 to $2004(n=14,37 \%)$, which included one special issue and one mini-series on related topics; three studies are included from Knotek and Sandoval's (2003a) special issue on CCC in JEPC, and three studies are included from Ingraham and Meyer's (2000) mini-series on multicultural and crosscultural school consultation in School Psychology Review. Other five-year periods from our sample include fewer studies (i.e., 1995-1999: $n=4,11 \%$ and 2005-2009: $n=7,18 \%)$.

\section{Theme 1: System-level Factors Matter for How Consultation Proceeds}

Three system-level/contextual factors that influenced the success or lack of success in consultation surfaced across multiple studies: (1) the availability of resources such as time; (2) the establishment of clear consultation expectations; and (3) the influence of building administrators.

Time as a resource. Consultative problem solving, whether it takes place individually or in a team, requires commitment of time. To begin, time is needed for 
consultants and consultees to develop collaborative relationships (e.g., Denatale, 2013; Etscheidt \& Knesting, 2007; Hazel, Pfaff, Albanes, \& Gallagher, 2014; HenningStout \& Bonner, 1996; Newman, Salmon, Cavanaugh, \& Schneider, 2014). Throughout the consultation, time is needed if consultee learning is to be a consultation priority (e.g., Babinski \& Rogers, 1998; Knotek, Rosenfield, Gravois, \& Babinski, 2003; Massé, Couture, Levesque, \& Bégin, 2013; Truscott \& Truscott, 2004). These derivatives of time - developing relationships and multi-directional learning - are recognized hallmarks of CCC (Lambert, 2004; Meyers, 1973).

Consultee participants in multiple studies reported having limited or no time to spare for individual or team-based consultation, attributing that limitation to hectic schedules, not wanting to delay service delivery to children or not perceiving the consultation to be a valuable use of time (e.g., Denatale, 2013; Meyers, 2002; Meyers, Valentino, Meyers, Boretti, \& Brent, 1996; Newman et al., 2014; Rubinson, 2002; Slonski-Fowler \& Truscott, 2004; Truscott \& Truscott, 2004). For example, Meyers (2002) reflected regarding a failed school reform initiative, approached via organizational consultation:

They stated that there were more meetings than they had originally expected and that the meetings were repetitive, uninformative, occasionally far away, and frequently planned at the last minute and ran overtime ... teachers felt the project asked too much of them in their busy schedules. (p. 173) In some studies, successful adjustments of individual or system schedules allowed time for consultation (e.g., Etscheidt \& Knesting, 2007; Hazel et al., 2014; Knotek, 2012). At the same time, other studies revealed that reworking schedules is not a 
sufficient solution if a team-based process is not valued, or viewed as viable (e.g., Rubinson, 2002).

By contrast, consultees prioritized time for consultation when its value (i.e., effectively addressing the problem of concern and/or enhancing the consultee's professional growth) was clear (e.g., Athanasiou, Geil, Hazel, \& Copeland, 2002; Denatale, 2013; Etscheidt \& Knesting, 2007; Hazel et al., 2014; Knotek, Babinski, \& Rogers, 2002). For example, an administrator/consultee expressed: "I got to the point when I was looking forward to our meetings and that higher level of discussion ... it kind of added the reason you go to school to do this work" (Denatale, 2013, p. 477).

Understanding school culture and establishing clear expectations. Data indicate that clarity of expectations and procedures matters in the development of consultation relationships and the process of how consultation proceeds. Authors referred to this early phase of consultation with terminology such as "engagement" (Denatale, 2013); “articulating consultative roles” (Frankel, 2006); “joining up" /"establishing a collaborative foundation” (Hasselbusch \& Penman, 2008); “contract negotiation” (Meyers, 2002); "entry/contracting” (Newman et al., 2014); and "identifying the needs and building a community" (Al Otaiba, Hosp, Smartt, \& Dole, 2008). Two tasks typical to this early stage were (1) understanding school culture, and (2) discussing consultant, team, and consultee role expectations.

Understanding school culture. Data suggest successful consultation begins with consultants gaining understanding and being responsive to the culture of the district, school or classroom in which they are consulting. Several studies referenced 
"mismatches" between the assumptions or values guiding consultation and consultee systems. These misunderstandings, in turn, linked with partial or full failure of initiative implementation (e.g., Al Otaiba et al., 2008; Meyers, 2002; Newman et al., 2014; Rubinson, 2002).

As described by an early childhood resource consultant who strategically planned a change initiative through consultation: "You have to be able to look at a broad picture. What are all the factors involved? What is everybody's interest in this, in what's going on? And how does everyone feel about making changes?" (Frankel, 2006, p. 47). Questions about school culture may reveal important information about a system's potential receptiveness to consultation. For example, a participant in Rubinson's (2002) study of problem solving teams expressed: "Should a demanding project not directly related to alleviation of current stresses be brought into these already overburdened schools?" (p. 206). As concluded by Knotek (2012) following a study of instructional consultation in a rural school setting: "If consultants are not internal to the organization, it is critical that they obtain insider knowledge" and "as visceral a familiarity with the organization as possible" (pp. 5960). For internal consultants, too, understanding school culture is important, and relates to role perceptions and enactments in consultation interactions.

Role expectations and the expert problem. Consultants, whether internal or external to the system, may be perceived as outsiders rather than collaborative partners. This was coded in the present study as the "expert problem" because consultants in a number of studies felt that being perceived as experts limited their capacity to prioritize indirect services and was potentially detrimental to 
collaboration (e.g., Al Otaiba et al., 2008l; Babinski \& Rogers, 1998; Hasselbusch \& Penman, 2008; Henning-Stout \& Bonner, 1996; Knotek et al., 2003).

One participant in Henning-Stout and Bonner's (1996) study on the professional lives of school psychologists stated of her consultation work: "My meetings with her are all very draining, probably because I am supposed to be the expert and [student] has me struggling for ideas, while the teacher is at her wit's end..." (p. 55). Another participant suggested being "cast as the expert ... gives me greater power and credibility, but it creates distance and intimidation." (p. 55). As written by Al Otaiba et al. (2008) regarding one participant, a reading coach, "Perhaps because of her expertise, even though she had been a classroom teacher, teachers may not have viewed her as 'one of them.'” (p. 149). In other words, an "us" (teachers) versus "you" (specialists) divide was present where consultees viewed consultants as lacking the empathy or pragmatic knowledge to support them.

"Relinquishing the expert role" (Knotek et al., 2003) was described as challenging but helpful in mitigating the perceived pressure consultants may feel to have silver bullet solutions to complex problems:

As a reading specialist [in the consultant role] sometimes teachers come up and say 'I have this problem,' and then you [the specialist] want to come up with the solution ... So at first I wanted to jump right in and say, "This is what you should do...' Boy, stepping back, that was very hard. (Knotek et al., 2003, p. 320) 
As reported by another consultant in the same study, "Sometimes you [as the specialist] don't know what the solution is ... This process really takes the pressure off a special education person, speech person, reading specialist" (p. 320). The reason the "expert problem" is coded as a subtheme of system-level factors is because consultative approaches (e.g., expert versus collaborative), may be negotiated during the entry/contracting stage of problem solving, and are often impacted by organizational (e.g., school) culture.

Administrator involvement. A final major component of the systems context is the role of administration (e.g., building principals). Positive involvement by administrators (e.g., stimulating buy-in; building a receptive/supportive school climate; valuing teacher input) appears facilitative of consultation efforts (e.g., Etscheidt \& Knesting, 2007; Frankel, 2006; Hazel et al., 2014; Knotek, 2012; Young \& Gaughan, 2010). For example, Hazel et al. (2014) observed a reciprocal process between teachers and administration: "When teachers saw that building administrators and district personnel were designing or revising systems based on needs that they had identified in their consultation, the teachers became much more invested in the process and vocal" and vice versa (p. 417). In contrast, a lack of administrator accountability for consultation processes (e.g., Slonski-Fowler \& Truscott, 2004) and administrators pressuring consultees to participate in consultation (e.g., McDougal, Nastasi, \& Chafouleas, 2005) were found to be detrimental to consultation.

Theme 2: Establishing Consultation Coherence 
Borrowing terminology from Webster et al. (2003), originally used to describe communication in a new teacher consultation group, our sample included both "coherent" and "incoherent" consultative interactions. Incoherent consultation includes relational and problem-solving processes that are unsystematic, not logically connected, inconsistent, irrelevant, or non-collaborative. Incoherent consultations involved premature leaps into advice giving or interventions before the appropriate problem solving stage, and lacked accountability/documentation. In contrast, coherent consultation included clear structures, such as prioritization of concerns, well-defined and systematically implemented problem-solving stages, and clear process accountability and documentation.

\section{Premature advice giving/rushing through problem solving stages}

contributes to incoherence. Rushing consultative problem solving, particularly premature movement into intervention before the completion of problem identification and analysis, occurred in a number of studies (e.g., Babinski \& Rogers, 1998; Meyers et al., 1996; Newman et al., 2014; Webster, Knotek, Babinski, Rogers, \& Barnett, 2003). Studies in this review indicate that rushing to intervene relates to the limited time available for consultation as well as the pressure consultants may feel to conform to an expert role (e.g., Babinski \& Rogers, 1998; Henning-Stout \& Bonner, 1996; Newman et al., 2014). Further, jumping to intervene relates to novice consultants' fragile knowledge of content and process (e.g., Benn, Jones, \& Rosenfield, 2008; Henning-Stout, 1999; Newell \& Newell, 2011; Newman, 2012). For example, premature advice giving/intervention appears to increase consultation incoherence. Examples of consequences found in the data include: impeding 
consultees' construction of new perspectives on work problems, obstructing the coordination process between consultant and consultee (Webster et al., 2003), limiting consultees' ownership of solutions (Babinski \& Rogers, 1998), limiting solutions to outside of the classroom setting such as pullout interventions with specialists (Meyers et al., 1996), and limiting data collection methods and quality (Meyers et al., 1996; Newell and Newell, 2011). Although occasions might exist where advice-giving or quick intervention is warranted in consultation (e.g., crises), such instances were not present in the dataset, and advice giving/rushing through problem solving stages was generally reported with a pejorative interpretation.

Consultation structures contribute to coherence. Enacting a structured problem solving process strengthens consultative interactions, and is viewed positively by consultees (e.g., Babinski \& Rogers, 1998; Benn et al., 2008; Etscheidt \& Knesting, 2007; Knotek et al., 2003; Young \& Gaughan, 2010). Structures found to be valuable across multiple studies in our sample include collaborative completion of structured forms and problem solving notes, and systematically prioritizing a single concern for problem solving. The benefit of prioritizing a single concern is illustrated by a quote from a problem solving team member in Etscheidt and Knesting's (2007) study of an exemplary problem solving team:

It's somewhat a relief that we're told to focus on one thing ... It's tough to justify to the teacher because they want to fix everything and they want to fix it now ... At the same time, it's practical. We can't do everything (p. 278). As a result of coherence, more time was spent in problem identification; consultation participants could articulate more observable, measurable, and 
ecological concerns; and both consultants and consultees viewed consultation processes as pragmatic rather than cumbersome. In contrast, teams without strong structures may have goals that are unclear or confusing to team members or consultees, provide interventions that are impractical or meaningless to consultees, and lack accountability for outcomes (e.g., Meyers et al., 1996; Slonski-Fowler \& Truscott, 2004). In other words, multiple studies provided evidence that incoherence during consultation is often manifested via a lack of appropriate structures informing the consultation process, which can be detrimental to problem solving. Findings regarding coherence/incoherence were particularly evident in studies of team-based consultation.

\section{Theme 3: Consultee Voice, Social-Emotional Support and Learning}

A wealth of data from the studies included in this QM indicates that consultation has the potential to provide social-emotional (SE) supports and opportunities for professional learning to consultees (e.g., Al Otaiba et al., 2008; Athanasiou et al., 2002; Babinski \& Rogers, 2002; Etscheidt \& Knesting, 2007; Frankel, 2006; Hasselbusch \& Penman, 2008; Hazel et al., 2014; Ingraham, 2003; Knotek et al., 2002; Knotek et al., 2003; Masse et al., 2013; Truscott \& Truscott, 2004; Young \& Gaughan, 2010). However, when consultees are not viewed or treated as valuable, coordinate partners this potential is not realized.

Consultation as a "lifeline." In a study of consultation provided by school psychologists to classroom teachers (Athanasiou et al., 2002), one consultee referred to the consultant as a "lifeline" in difficult situations (p. 291), a term that is representative of SE supports valued by consultees in multiple studies. Examples of 
SE supports include consultants listening, sharing ideas, and providing direct services to students when consultees feel overwhelmed. With strong SE supports, trust and credibility are established in the consultation relationship, consultees can better navigate complex interpersonal and systems-level dynamics, and consultee feelings of isolation are mitigated. The camaraderie established through SE supports may be considered akin to having coordinate status, or a nonhierarchical relationship, in which giving and receiving support is accepted and valued by consultees (e.g., Babinski \& Rogers, 1998; Webster et al., 2003). For example, teacher-consultees in a study by Babinski and Rogers (1998) described themselves as "in the same boat" with each other (p. 301), a community of professionals working through similar challenges in similar ways.

Consultee learning. Consultee learning includes reflective practice - gaining new perspectives regarding self and others and learning professionally relevant content or skill. As representatively summarized by one consultee in a study by Massé et al. (2013): “[Consultation] enabled me to question myself to tell myself 'well, that I would do differently'." (p. 335). Reflective practice for consultees included strengthening professional identity (e.g., "self as teacher", as described by Babinski \& Rogers, 1998); increasing professional self-efficacy (e.g., Knotek et al., 2002); and establishing more observable/measurable and positive views of clients/students (e.g., Massé et al., 2013). Consultees also indicated appreciation for learning relevant content and skill through consultation (e.g., working with a preschool student with cerebral palsy [Frankel, 2006], responding to students exhibiting extreme and disruptive classroom behaviors [Massé et al., 2013], 
employing relational process skills such as cultural vulnerability [Ingraham, 2003]). Consultant modeling of new skills in the context of classroom interactions appears to be an important way this learning occurs (Al Otaiba et al., 2008; Athanasiou et al., 2002; Frankel, 2006; Newell, Newell, \& Looser, 2013a; Summers, Funk, Twombly, Waddell, \& Squires, 2007). For example, a consultant's self-disclosure about vulnerability when learning about new cultures may create safe conditions for consultee learning to occur (Ingraham, 2003).

Consultee voice. As expressed by Knotek (2012): “We must not underestimate the implications that an innovation's implementation can have on a person's professional identity and concomitant work tasks" (p. 60). Indeed, the synthesized data suggest that consultation problems and solutions should be coconstructed with consultees (e.g., Etscheidt \& Knesting, 2007; Knotek et al., 2003; Frankel, 2006; Hasselbusch \& Penman, 2008; Knotek, 2012; Hazel et al., 2014; Massé et al., 2013; Young \& Gaughan, 2010). Furthermore, unsuccessful individual and team consultations are characterized by insufficient attention to the voices and needs of consultees (e.g., Knotek, 2003a; Meyers et al., 1996; Slonski-Fowler \& Truscott, 2004; Webster et al., 2003). In other words, consultees are most likely to contribute to intervention implementation when they contribute significantly to problem definition, problem analysis and intervention design. For example, consultants in Frankel's (2006) study streamlined consultation interactions to take place within a busy early childhood setting thereby building authenticity and ensuring consultee receptiveness to intervention planning and implementation. 
Conversely, when consultee input is devalued, or interventions are viewed as irrelevant to the consultee's practices, consultees will likely disengage from the consultation process (e.g., Knotek, 2003a; Meyers et al., 1996; Slonski-Fowler \& Truscott, 2004). A striking illustration of this is provided by a teacher-consultee regarding her perception of team-based consultation:

I was kind of like, crud, what just happened in there? I came in for a kid who was ADHD ... trying to find out different strategies on how to help ... I walk out of there with a theory that this kid is gifted and talented now. I just kind of walked out of there and said, 'What the heck happened here?" ... They didn't hear me ... I know I'm not invisible." (Slonski-Fowler \& Truscott, 2004, p. 20)

\section{Theme 4: Consultation as Ecologically Oriented, Culturally Responsive - and}

\section{are these distinct?}

The interrelated constructs of ecological orientation to consultative problem solving (see Sheridan \& Gutkin, 2000) and culturally responsive consultation were present in the majority of studies in our sample, either due to their application or lack of application in consultation interactions.

Ecological approach. Applying an ecological approach to problem solving means moving outside of a child to understand how environmental factors influence the problem of concern. Consultees in our sample tended to predominately identify child-centered concerns, while consultants promoted more ecological understandings as the bases for problem solving (e.g., Athanasiou et al., 2002; Hasselbusch \& Penman, 2008; Knotek, 2003a; Knotek, 2012; Knotek et al., 2003; 
Lopez, 2000; Rubinson, 2002; Summers et al., 2007; Young \& Gaughan, 2010). In a few studies (Newell, 2010b; Newell \& Newell, 2011; Newell, Newell, \& Looser, 2013b) novice consultants disregarded an ecological lens during simulated consultation interactions.

Ecological problem definition. How problems are conceptualized in consultation influences how consultants and consultees perceive solvability (Knotek, 2003a). For example, a teacher-consultee in Athanasiou et al.'s (2002) study described a student's problem of "emotional well-being" as "something inside that I would hope that could be fixed" (pp. 278-279). Rubinson (2002) found that consultations characterized by "attribution of within child-etiology" (p. 204) resulted in direct interventions implemented by specialists rather than in consultee engagement. Consultant practices that support ecological problem solving include: breaking down problematic language (e.g., Benn et al., 2008; Knotek, 2003a, 2003b; Knotek et al., 2003); incorporating ecological, contextually-relevant assessment practices and data (e.g., Hasselbusch \& Penman, 2008); increasing structure to support sufficient problem definition clarity (e.g., Young \& Gaughan, 2010); and seeking supervision feedback on communication skills and problem identification using audio-recorded sessions (e.g., Newman, 2012; Summers et al., 2007).

Cultural responsiveness. Data unambiguously indicate that cultural awareness and responsiveness should be incorporated into consultation (e.g., Goldstein \& Harris, 2000; Ingraham, 2003; Knotek, 2003a; Knotek, 2012; Knotek et al., 2003; Lopez, 2000; Meyers, 2002; Newell, 2010b; Newell, Newell, \& Looser, 2013b; Tarver Behring, Cabello, Kushida, \& Murguia, 2000). However, what 
precisely is meant by cultural responsiveness varied across studies. According to Knotek (2012), cultural responsiveness includes understanding and applying knowledge of diversity and culture; affirmation of diversity; connections between home and school; and diverse instructional and assessment strategies. Applying this broad definition, cultural responsiveness presented itself in our sample of studies through consultants adjusting the consultation based on cultural differences (e.g., race, ethnicity, language, SES).

Adjusting consultation practices may also be important when differences exist between the culture represented in consultation initiatives (e.g., problem solving teams) and the systems in which intervention will occur (e.g., between school culture, and the related cultural makeup of the students, families, and teachers in the school) (e.g., Knotek, 2012; Meyers, 2002). Although a number of studies presented findings to suggest that cultural differences and similarities in consultation are meaningful, our research team was unable to synthesize consistent findings on how to be culturally responsive during individual or systems-level consultation.

\section{Are an ecological approach and cultural responsiveness distinct, and} how do these differ from storytelling? Illustrating the lack of evidence to support culturally responsive and effective consultation is the tension in the data suggesting that cultural considerations are distinct from an ecological orientation. Although several studies suggest that "child-centered" problem definitions, including "storytelling" about students' families, may muddle consultative problem-solving efforts, other studies suggest that culturally competent consultation requires 
focused discussion of student and family variables. For instance, take the following two consultant quotes from separate studies:

It's a really messy situation at home and I should tell you about it. There are five children in the family, three in this school, and all of them under 8 . There are two brothers in the same class who have a different father. Mom works and the children set Mom's trailer on fire earlier this year, they rolled a van into traffic, sat on their infant brother's legs and broke [one]. (Knotek, 2003a, p. 7)

If a child comes off that bus and something happened at their house that night, until they get somebody to listen to what went on they're not going to be able to go in that classroom and concentrate on what needs to be done in that classroom. (Knotek, 2012, p. 55)

The first of these two quotes may be considered storytelling, unlikely to be facilitative of problem solving efforts, while the second may be considered culturally responsive in support of student and family needs. The precise complementarity of the ecological orientation and cultural responsiveness is not clear in the data available to this QM and may require further consideration.

\section{Theme 5: Training Supports Consultants' and Teams' Application of Relational Process Skills}

The fifth theme that emerged from the data indicates that consultants require sufficient training to apply relational process skills. Process-oriented consultation training was a focus of several studies (e.g., Henning-Stout, 1999; Newell, Newell, \& Looser, 2013a, 2013 b; Newman, 2012; Summers et al., 2007), and 
the need for such training was considered in the discussion/implication sections of several others (e.g., Benn et al., 2008; Denatale, 2013; Frankel, 2006; Hasselbush \& Penman, 2008; Ingraham, 2003; Lopez, 2000; Meyers et al., 1996; Newell, 2010a, 2010b; Newell, 2011; Newman et al., 2014; Rubinson, 2002; Slonski-Fowler \& Truscott, 2004; Tarver Behring et al., 2000). The confluence of these studies suggests that consultation training is strongest when it emphasizes interpersonal factors such as effective communication, relationship building, and how to address cultural issues during consultation.

Data also suggest that consultants are not receiving sufficient training, or are unsuccessful in applying process skills in simulated consultation experiences (e.g., Newell, Newell, \& Looser, 2013a, 2013 b; Newell, 2010a, 2010b; Newell, 2011). Supervision of consultation that includes review of audio/video recordings, engagement in self-reflection, and receiving supervisor feedback, may aid the establishment of relational, process-oriented skills (e.g., Hasselbusch \& Penman, 2008; Henning-Stout, 1999; Newell, 2012; Newman, 2012; Summers et al., 2007). As expressed by a consultant in a study by Newman (2012): "I've been feeling like the process [in the consultation] has been getting in the way of talking about content that's effective and productive. It seems like what we've talked about [in supervision] is a way to rein both of them back" (p. 271).

Of note, a number of authors suggest that specific training is needed for consultants to establish cultural responsiveness in consultation (e.g., Ingraham, 2003; Lopez, 2000; Newell, 2010a, 2012b; Newell, 2012; Newell, Newell, \& Looser, 2013b). However, related to Theme 4 (i.e., cultural responsiveness), precisely what 
this competence entails is not made explicitly clear and requires further investigation.

\section{Limitations}

Although steps were taken to enhance the study's dependability and credibility, several limitations to this work should be noted. A first limitation, present in any research synthesis, quantitative or qualitative, is that the findings may only reflect the studies that are integrated within the analysis. We included studies with credibility features specified explicitly and implicitly by the authors (see Table 1), the latter a potential risk to trustworthiness. Admittedly, not all studies seem to have been conducted with equal rigor or thickness of description. However, the research team members were clear, consistent and in consensus on the selection criteria applied. A second limitation to this study is that two of the researchers authored a total of four articles in our sample, which may put these parts of the analysis at risk for bias. However, these researchers comprised only one third of the research team and did not code their own studies.

A third limitation is that all of the team members had familiarity with specific studies prior to the analysis, which represents a potential challenge from a priori assumptions. However, several studies that team members had not previously encountered were also identified and included in the analysis. Further, the team members reduced potential biases by engaging in reflexivity as they shared both a priori assumptions and emerging understandings of the data as the study progressed. A fourth limitation to this study is that all team members were engaging in metasynthesis for the first time, making the research process in some 
ways like "building a plane while flying it." However, three of the researchers had expertise in qualitative research, and one acted in the role of research auditor upon joining the team. The team also engaged in shared readings/discussions about QM and other qualitative methodology and methods during the process.

\section{Next Research Priorities}

The "future research" sections from the 38 studies in our sample were instructive and wide-ranging. With the exception of studies by the same authors, the resultant spectrum of conclusions and insights may be understood as both rich in guidance and as evidence of the "little islands of knowledge problem" our QM investigation attempted to bridge. We take this as both a challenge and opportunity for future QM focused on deepening our knowledge and practice of CCC and connected relational processes of consultation. Table 4 explores key findings from the QM reported herein. We present these data theme-by-theme, with recommendations of future research questions. Related to the summaries in Table 4, a few points regarding future research directions are worth highlighting.

First, the reader may notice that all areas and questions emerging from the studies included in our QM either directly or indirectly focus on relationships (e.g., consultant-administrator; consultant-consultee; consultee-student; consultantstudent; consultant-consultee-student). School consultation is inescapably a relational endeavor (Henning-Stout \& Bonner, 1996), which is clearly captured in our research sample and must be accounted for in future research. Second, the research areas and questions we propose in Table 4 beg for qualitative and mixed methods approaches to investigation. It is not that these should be the exclusive 
methods applied to study CCC and relational processes in consultation; indeed, quantitative methods can augment our understanding of CCC (Knotek \& Hylander, 2014). However, research on relational processes vital to consultation effectiveness is well suited to qualitative exploration. Qualitative research focuses on establishing in-depth understanding of dynamic processes and the complex relational context in which consultation takes place (see Meyers et al., 2014).

Third, research on CCC and relational processes can significantly extend practical understandings of consultees. Contemporary school-based consultation research emphasizes client outcomes as a "gold-standard" (i.e., how do students benefit from school consultation?). However, consultees must be active agents of that change. Thus we must understand (a) consultation's beneficial effects for consultees, and (b) how consultees' existing skills and dispositions can contribute to effective consultation (e.g., CCC-driven peer support groups). Such a lens can also extend the effectiveness of consultation as embedded professional development. Fourth, we need to know more about cultural responsiveness in consultation. Cultural differences and similarities in consultation constellations are significant variables in the unfolding of both individual- and systems-level consultation. The current construct of culturally responsive practice contributes to better consultation outcomes only if it has treatment (i.e., enacted) validity. Our findings indicate that considerably more clarity is needed regarding (a) what precisely cultural responsiveness means, (b) how consultants know it when they see it, and (c) how, during in-service and pre-service training, consultants may be guided in developing and applying cultural responsiveness in their work. 
Multiple research trajectories. One member checker reminded our research team that it is important to recognize the results of this study as situated in the larger study of consultation/collaborative services. Thus, we offer the recommendations outlined here as some among many possibilities for further study. Two areas explicitly mentioned by member checkers for future research include: (1) investigating how personal beliefs/characteristics of the consultant may have an impact on both (a) the type(s) of consultation offered, and (b) the match between consultant and consultee; and (2) documenting and describing the consultation constellations investigated, including (a) considerations such as culture, race, ethnicity, and/or cultural responsiveness of consultants, consultees, and clients, and (b) measures of the impact these constellations have on consultation process and outcomes. Finally, three member checkers commented on the potential for further, more complex data analysis through examination of different perspectives of participants, for example, in different educational roles, career phases, or developmental stages.

Future application of QM. This project is the first application of a QM methodology in the study of school consultation. Our efforts have afforded us opportunity to generate interpretive synthesis of a voluminous amount of data directly defining CCC and relational processes. The studies we considered revealed two additional considerations for investigation, both likely to be elaborated with QM and to provide evidence of the utility of metasynthesis as a research methodology in consultation specifically, and our disciplines more generally. First is a content focus. The study of social justice in schools, for example, represents one of many areas that 
has yet to be cohesively integrated, and could benefit from a QM. Second, any application of QM methodology is only as strong as the integrity and rigor of the methods applied. Therefore, researchers who implement QM in the future and meticulously describe their approaches will provide further evidence of QM's methodological validity.

\section{Conclusion or Beginning?}

This study was the first attempt to empirically synthesize what we know about CCC and related processes of consultation, integrating data from 38 qualitative studies. Several broad themes emerged with consistency across multiple studies in the sample. Research has demonstrated that systems-level factors matter for consultation in a variety of ways, as does the structure of consultation implementation. Active consultee participation in the consultation process also seems to matter, including consultees having a voice in the process, viewing consultation as a form of social-emotional support, and a context for professional development or learning. The application, or lack thereof, of an ecological perspective and cultural responsiveness also emerged as relevant variables; however, it seems that further clarification is needed regarding how these variables converge and diverge. Finally, several studies suggest that consultants' application of relational skills is supported through process-focused training.

When it comes to CCC and related approaches to consultation, perhaps we know more than we previously thought. However, this study also generated more questions than answers, as is evident when looking at Table 4. We hope identifying areas for future research built on a foundation of prior research will help catalyze a 
focused, cohesive agenda for the future. To be certain, much work remains to further our evidence-based understanding of the interpersonal processes that are relevant to school-based consultation. 
Table 1.

Chronological, Detailed List of Studies Included in the Final Sample

\begin{tabular}{|c|c|c|c|c|c|c|}
\hline Year & Author(s) & Processes Studied & $\begin{array}{c}\text { Methodological } \\
\text { Approach }\end{array}$ & $\begin{array}{l}\text { Consultation } \\
\text { Model(s) }\end{array}$ & Sample $(N$, roles $)$ & $\begin{array}{c}\text { Author- } \\
\text { Identified } \\
\text { Credibility } \\
\text { Features } \\
\end{array}$ \\
\hline 1996 & $\begin{array}{l}\text { Henning- } \\
\text { Stout \& } \\
\text { Bonner }\end{array}$ & $\begin{array}{l}\text { Extent of } \\
\text { collaboration in } \\
\text { school } \\
\text { psychologists' } \\
\text { professional practice }\end{array}$ & Ethnography & Not specified & 8 consultants & $\begin{array}{l}\text { Statement of } \\
\text { positionality; } \\
\text { adherence to } \\
\text { ethnographic } \\
\text { methods }\end{array}$ \\
\hline 1996 & $\begin{array}{l}\text { Meyers, } \\
\text { Valentino, } \\
\text { Meyers, } \\
\text { Borretti, \& } \\
\text { Brent }\end{array}$ & $\begin{array}{l}\text { Educators' } \\
\text { preferences and } \\
\text { suggestions for } \\
\text { improvement when } \\
\text { working with } \\
\text { consultation teams }\end{array}$ & Case study & $\begin{array}{l}\text { CCC (Teacher } \\
\text { and Systems) }\end{array}$ & $\begin{array}{c}134 \\
\text { multidisciplinary } \\
\text { team members }\end{array}$ & $\begin{array}{c}\text { Data } \\
\text { Triangulation }\end{array}$ \\
\hline 1998 & $\begin{array}{l}\text { Babinski \& } \\
\text { Rogers }\end{array}$ & $\begin{array}{l}\text { Contributions of } \\
\text { group-based CCC to } \\
\text { community- } \\
\text { orientation among } \\
\text { novice teachers }\end{array}$ & Not specified & $\mathrm{CCC}$ & 5 teacher c-tees & $\begin{array}{c}\text { Data } \\
\text { triangulation }\end{array}$ \\
\hline 1999 & $\begin{array}{l}\text { Henning- } \\
\text { Stout }\end{array}$ & Experiences of CITs & $\begin{array}{c}\text { Ethnography } \\
\text { (Phenomenological } \\
\text { lens) }\end{array}$ & $\mathrm{BC}$ & 8 CITs & $\begin{array}{c}\text { Member } \\
\text { checking; audit }\end{array}$ \\
\hline 2000 & $\begin{array}{l}\text { Goldstein \& } \\
\text { Harris }\end{array}$ & $\begin{array}{l}\text { Family engagement } \\
\text { in consultation as a } \\
\text { function of }\end{array}$ & Case Study & SST & 2 secondary SSTs & $\begin{array}{c}\text { Prolonged } \\
\text { engagement; } \\
\text { data }\end{array}$ \\
\hline
\end{tabular}




\begin{tabular}{|c|c|c|c|c|c|c|}
\hline Year & Author(s) & Processes Studied & $\begin{array}{c}\text { Methodological } \\
\text { Approach }\end{array}$ & $\begin{array}{l}\text { Consultation } \\
\text { Model(s) }\end{array}$ & Sample $(N$, roles $)$ & $\begin{array}{l}\text { Author- } \\
\text { Identified } \\
\text { Credibility } \\
\text { Features }\end{array}$ \\
\hline & & $\begin{array}{l}\text { cultural/linguistic } \\
\text { background and } \\
\text { expectations of } \\
\text { education }\end{array}$ & & & & $\begin{array}{l}\text { triangulation; } \\
\text { peer debriefing }\end{array}$ \\
\hline 2000 & Lopez & $\begin{array}{l}\text { Challenges in IC } \\
\text { when } \\
\text { communicating via } \\
\text { interpreters }\end{array}$ & $\begin{array}{c}\text { Case Study } \\
\text { (Naturalistic } \\
\text { Inquiry; } \\
\text { Constructivist) }\end{array}$ & $\mathrm{IC}$ & $\begin{array}{c}11 \text { consultants, } 3 \\
\text { teacher c-tees, } 5 \\
\text { student clients, } 2 \\
\text { guidance } \\
\text { counselor c-tees, } 6 \\
\text { interpreters }\end{array}$ & $\begin{array}{c}\text { Prolonged } \\
\text { engagement; } \\
\text { data } \\
\text { triangulation; } \\
\text { peer } \\
\text { debriefing; } \\
\text { member } \\
\text { checking; thick } \\
\text { description }\end{array}$ \\
\hline 2000 & $\begin{array}{l}\text { Tarver- } \\
\text { Behring, } \\
\text { Cabello, } \\
\text { Kushida, \& } \\
\text { Murquia, }\end{array}$ & $\begin{array}{l}\text { Presence/extent of } \\
\text { modifications to } \\
\text { consultation when } \\
\text { consultant and client } \\
\text { are of } \\
\text { similar/different } \\
\text { racial/ethnic } \\
\text { background }\end{array}$ & Case Study & $\begin{array}{c}\text { PS/BC, MHC, } \\
\text { OC }\end{array}$ & $\begin{array}{l}28 \text { first-year } \\
\text { consultants }\end{array}$ & $\begin{array}{l}\text { Detailed, clear } \\
\text { coding process }\end{array}$ \\
\hline 2002 & $\begin{array}{l}\text { Athanasiou, } \\
\text { Geil, Hazel } \\
\text { \& Copeland }\end{array}$ & $\begin{array}{l}\text { Teacher beliefs } \\
\text { about student } \\
\text { behavior in relation } \\
\text { to consultation } \\
\text { effectiveness }\end{array}$ & $\begin{array}{l}\text { Case Study } \\
\text { (Collective) }\end{array}$ & $\begin{array}{c}\text { BC or } \\
\text { Solution- } \\
\text { Oriented }\end{array}$ & $\begin{array}{l}4 \text { consultants, } 4 \\
\text { teacher c-tees }\end{array}$ & $\begin{array}{l}\text { Triangulation; } \\
\text { peer review; } \\
\text { negative case } \\
\text { analysis; } \\
\text { clarifying } \\
\text { researcher } \\
\end{array}$ \\
\hline
\end{tabular}




\begin{tabular}{|c|c|c|c|c|c|c|}
\hline Year & Author(s) & Processes Studied & $\begin{array}{c}\text { Methodological } \\
\text { Approach }\end{array}$ & $\begin{array}{l}\text { Consultation } \\
\text { Model(s) }\end{array}$ & Sample $(N$, roles $)$ & $\begin{array}{l}\text { Author- } \\
\text { Identified } \\
\text { Credibility } \\
\text { Features }\end{array}$ \\
\hline & & & & & & $\begin{array}{l}\text { biases; thick } \\
\text { description }\end{array}$ \\
\hline 2002 & $\begin{array}{l}\text { Knotek, } \\
\text { Babinksi, \& } \\
\text { Rogers }\end{array}$ & $\begin{array}{l}\text { Evolution of new } \\
\text { teachers' beliefs } \\
\text { about children and } \\
\text { self }\end{array}$ & $\begin{array}{c}\text { Ethnography } \\
\text { (Microethnography) }\end{array}$ & $\mathrm{CCC}$ & 5 teachers & $\begin{array}{c}\text { Data } \\
\text { triangulation }\end{array}$ \\
\hline 2002 & Meyers & $\begin{array}{l}\text { Consultation } \\
\text { contract negotiation }\end{array}$ & Case Study & $\begin{array}{c}\text { Cross- } \\
\text { Cultural and } \\
\text { OC }\end{array}$ & $\begin{array}{l}1 \text { consultant; } 1 \\
\text { principal c-tee; } 12 \\
\text { other school staff } \\
\text { c-tees; } 14 \text { parents }\end{array}$ & $\begin{array}{c}\text { Data } \\
\text { triangulation; } \\
\text { member } \\
\text { checking; peer } \\
\text { debriefing; } \\
\text { prolonged } \\
\text { engagement }\end{array}$ \\
\hline 2002 & Rubinson & $\begin{array}{l}\text { Influence of urban } \\
\text { high school setting } \\
\text { on collaborative } \\
\text { teams }\end{array}$ & Naturalistic Inquiry & Not specified & $\begin{array}{c}3 \text { consultants; } 12 \\
\text { teams }\end{array}$ & $\begin{array}{c}\text { Prolonged } \\
\text { engagement; } \\
\text { data } \\
\text { triangulation; } \\
\text { peer debriefing }\end{array}$ \\
\hline 2003 & Ingraham & $\begin{array}{l}\text { Influence of cultural } \\
\text { issues and cultural } \\
\text { competence during } \\
\text { CCC }\end{array}$ & $\begin{array}{c}\text { Case Study, } \\
\text { Naturalistic Inquiry }\end{array}$ & $\mathrm{CCC}$ & $\begin{array}{c}3 \text { CITs; } 3 \text { teacher } \\
\text { c-tees }\end{array}$ & $\begin{array}{c}\text { Member } \\
\text { checking; data } \\
\text { triangulation }\end{array}$ \\
\hline $2003 a$ & Knotek & $\begin{array}{l}\text { Problem-solving } \\
\text { norms among SSTs } \\
\text { in poor, rural } \\
\text { schools serving } \\
\text { primarily African- }\end{array}$ & $\begin{array}{c}\text { Ethnography } \\
\text { (Microethnography) }\end{array}$ & SST & $\begin{array}{c}8 \text { members of } \\
\text { problem-solving } \\
\text { team }\end{array}$ & $\begin{array}{c}\text { Data } \\
\text { triangulation; } \\
\text { prolonged } \\
\text { engagement; } \\
\text { thick } \\
\end{array}$ \\
\hline
\end{tabular}




\begin{tabular}{|c|c|c|c|c|c|c|}
\hline Year & Author(s) & Processes Studied & $\begin{array}{l}\text { Methodological } \\
\text { Approach }\end{array}$ & $\begin{array}{l}\text { Consultation } \\
\operatorname{Model}(\mathbf{s})\end{array}$ & Sample $(N$, roles $)$ & $\begin{array}{l}\text { Author- } \\
\text { Identified } \\
\text { Credibility } \\
\text { Features } \\
\end{array}$ \\
\hline & & $\begin{array}{l}\text { American } \\
\text { populations }\end{array}$ & & & & description \\
\hline $2003 b$ & Knotek & $\begin{array}{l}\text { Change in problem } \\
\text { identification } \\
\text { language among } \\
\text { SST members }\end{array}$ & $\begin{array}{c}\text { Ethnography } \\
\text { (Microethnography) }\end{array}$ & $\mathrm{CCC}$ & 2 SSTs & $\begin{array}{c}\text { Data } \\
\text { triangulation; } \\
\text { prolonged } \\
\text { engagement; } \\
\text { member } \\
\text { checking; peer } \\
\text { debriefing }\end{array}$ \\
\hline 2003 & $\begin{array}{l}\text { Knotek, } \\
\text { Rosenfield, } \\
\text { Gravois, \& } \\
\text { Babinski }\end{array}$ & $\begin{array}{l}\text { Change in } \\
\text { consultees' } \\
\text { understanding of } \\
\text { work problems }\end{array}$ & $\begin{array}{c}\text { Ethnography } \\
\text { (Microethnography) }\end{array}$ & IC & $\begin{array}{l}13 \text { consultants; } 5 \\
\text { teacher c-tees }\end{array}$ & $\begin{array}{c}\text { Data } \\
\text { triangulation; } \\
\text { member } \\
\text { checking }\end{array}$ \\
\hline 2003 & $\begin{array}{l}\text { Webster, } \\
\text { Knotek, } \\
\text { Babinski, } \\
\text { Rogers, \& } \\
\text { Barnet }\end{array}$ & $\begin{array}{l}\text { Change in problem- } \\
\text { solving language } \\
\text { and effectiveness } \\
\text { during team } \\
\text { interaction }\end{array}$ & $\begin{array}{c}\text { Ethnography } \\
\text { (Microethnography) }\end{array}$ & $\mathrm{CCC}$ & $\begin{array}{l}\text { 1 CIT; } 7 \text { teacher c- } \\
\text { tees }\end{array}$ & $\begin{array}{c}\text { Data } \\
\text { triangulation }\end{array}$ \\
\hline 2004 & $\begin{array}{l}\text { Slonski- } \\
\text { Fowler \& } \\
\text { Truscott }\end{array}$ & $\begin{array}{l}\text { Influences on } \\
\text { teachers' perceptions } \\
\text { of consultation } \\
\text { teams }\end{array}$ & Ethnography & $\begin{array}{l}\text { Pre-referral } \\
\text { PS team }\end{array}$ & 12 teachers & $\begin{array}{l}\text { Data } \\
\text { triangulation; } \\
\text { member } \\
\text { checking; peer } \\
\text { review } \\
\end{array}$ \\
\hline 2004 & $\begin{array}{l}\text { Truscott \& } \\
\text { Truscott }\end{array}$ & $\begin{array}{l}\text { Role of positive } \\
\text { psychology } \\
\text { principles in } \\
\text { increasing teachers' }\end{array}$ & Not Specified & Not specified & 12 teachers & $\begin{array}{l}\text { Data } \\
\text { triangulation; } \\
\text { consensus } \\
\text { coding } \\
\end{array}$ \\
\hline
\end{tabular}




\begin{tabular}{|c|c|c|c|c|c|c|}
\hline Year & Author(s) & Processes Studied & $\begin{array}{c}\text { Methodological } \\
\text { Approach }\end{array}$ & $\begin{array}{l}\text { Consultation } \\
\text { Model(s) }\end{array}$ & Sample $(N$, roles $)$ & $\begin{array}{l}\text { Author- } \\
\text { Identified } \\
\text { Credibility } \\
\text { Features }\end{array}$ \\
\hline & & $\begin{array}{l}\text { use of preventative } \\
\text { strategies in reading } \\
\text { instruction }\end{array}$ & & & & \\
\hline 2005 & $\begin{array}{l}\text { McDougal, } \\
\text { Nastasi, \& } \\
\text { Chafouleas }\end{array}$ & $\begin{array}{l}\text { Transfer of EBIs } \\
\text { into practice } \\
\text { contexts }\end{array}$ & Mixed & $\begin{array}{l}\text { BC (team- } \\
\text { based) }\end{array}$ & $\begin{array}{l}11 \text { consultants; } 2 \\
\text { teacher c-tees; } 3 \\
\text { social worker c- } \\
\text { tees }\end{array}$ & $\begin{array}{c}\text { Data } \\
\text { triangulation; } \\
\text { coder } \\
\text { agreement }\end{array}$ \\
\hline 2006 & Frankel & $\begin{array}{l}\text { Interactions between } \\
\text { resource consultants, } \\
\text { teachers, and parents } \\
\text { as preschool } \\
\text { programs } \\
\text { implemented } \\
\text { inclusive practices }\end{array}$ & $\begin{array}{c}\text { Case Study } \\
\text { (Comparative, } \\
\text { Naturalistic) }\end{array}$ & Not specified & 2 consultants & $\begin{array}{l}\text { Data } \\
\text { triangulation; } \\
\text { member } \\
\text { checking }\end{array}$ \\
\hline 2007 & $\begin{array}{l}\text { Etscheidt \& } \\
\text { Knesting }\end{array}$ & $\begin{array}{l}\text { Interpersonal } \\
\text { dynamics of } \\
\text { effective team-based } \\
\text { problem-solving }\end{array}$ & Case Study & $\begin{array}{l}\text { Pre-referral } \\
\text { problem- } \\
\text { solving team }\end{array}$ & $\begin{array}{c}9 \text { multi- } \\
\text { disciplinary team } \\
\text { members }\end{array}$ & $\begin{array}{c}\text { Data } \\
\text { triangulation; } \\
\text { member } \\
\text { checking; } \\
\text { multiple coders }\end{array}$ \\
\hline 2007 & $\begin{array}{l}\text { Summers, } \\
\text { Funk, } \\
\text { Twombly, } \\
\text { Waddell, \& } \\
\text { Squires }\end{array}$ & $\begin{array}{l}\text { Mentors' support of } \\
\text { educators' infant } \\
\text { mental health } \\
\text { service delivery }\end{array}$ & $\begin{array}{l}\text { Logic of Inquiry } \\
\text { Approach }\end{array}$ & $\begin{array}{l}\text { Mentoring } \\
\text { (Similar in } \\
\text { description to } \\
\text { CCC) }\end{array}$ & $\begin{array}{l}3 \text { consultants; } 16 \\
\text { home visitors/ } \\
\text { family specialist c- } \\
\text { tees, } 10 \\
\text { administrator c- } \\
\text { tees } \\
\end{array}$ & $\begin{array}{l}\text { Data } \\
\text { triangulation; } \\
\text { member } \\
\text { checking }\end{array}$ \\
\hline 2008 & $\begin{array}{l}\text { Al Otaiba, } \\
\text { Host, }\end{array}$ & $\begin{array}{l}\text { Challenges in } \\
\text { implementing }\end{array}$ & Mixed & $\begin{array}{c}\text { Reading } \\
\text { coaching and }\end{array}$ & $\begin{array}{c}1 \text { consultant; } 33 \\
\text { teacher c-tees }\end{array}$ & $\begin{array}{c}\text { Data } \\
\text { triangulation }\end{array}$ \\
\hline
\end{tabular}




\begin{tabular}{|c|c|c|c|c|c|c|}
\hline Year & Author(s) & Processes Studied & $\begin{array}{c}\text { Methodological } \\
\text { Approach }\end{array}$ & $\begin{array}{l}\text { Consultation } \\
\operatorname{Model}(\mathbf{s})\end{array}$ & Sample $(N$, roles $)$ & $\begin{array}{l}\text { Author- } \\
\text { Identified } \\
\text { Credibility } \\
\text { Features }\end{array}$ \\
\hline & $\begin{array}{l}\text { Smartt, \& } \\
\text { Dole }\end{array}$ & $\begin{array}{l}\text { coaching during } \\
\text { reading reform }\end{array}$ & & $\mathrm{BC}$ & & \\
\hline 2008 & $\begin{array}{l}\text { Benn, Jones, } \\
\& \\
\text { Rosenfield }\end{array}$ & $\begin{array}{l}\text { Relationship of } \\
\text { consultant } \\
\text { communication } \\
\text { behaviors and } \\
\text { competency levels }\end{array}$ & Mixed & IC & $\begin{array}{c}6 \text { archived } \\
\text { problem } \\
\text { identification } \\
\text { videos }\end{array}$ & $\begin{array}{l}\text { Intercoder } \\
\text { reliability; } \\
\text { expert panel }\end{array}$ \\
\hline 2008 & $\begin{array}{l}\text { Hasselbusch } \\
\text { \& Penman }\end{array}$ & $\begin{array}{l}\text { Practices and } \\
\text { experience of } \\
\text { consultation while } \\
\text { serving students } \\
\text { with ASD }\end{array}$ & Grounded Theory & Collaborative & 8 consultants & $\begin{array}{l}\text { Presupposition } \\
\text { interview; pilot } \\
\text { interview; peer } \\
\text { review; } \\
\text { member } \\
\text { checking }\end{array}$ \\
\hline $2010 \mathrm{a}$ & Newell & $\begin{array}{l}\text { Relationship } \\
\text { between consultation } \\
\text { procedures used and } \\
\text { decision-making } \\
\text { processes }\end{array}$ & Case Study & $\mathrm{PS} / \mathrm{BC}$ & 4 consultants & $\begin{array}{c}\text { Constant } \\
\text { comparison }\end{array}$ \\
\hline $2010 b$ & Newell & $\begin{array}{l}\text { Consultation } \\
\text { practices in multi- } \\
\text { racial contexts }\end{array}$ & Case Study & $\begin{array}{l}\text { Not specified } \\
\text { a priori }\end{array}$ & 4 consultants & $\begin{array}{c}\text { Foucaldian } \\
\text { discourse } \\
\text { analysis } \\
\end{array}$ \\
\hline 2010 & $\begin{array}{l}\text { Young \& } \\
\text { Gaughan }\end{array}$ & $\begin{array}{l}\text { Influences on the } \\
\text { improvement of } \\
\text { consultation teams }\end{array}$ & Case study & $\mathrm{BC}$ & 4 consultants & $\begin{array}{c}\text { Data } \\
\text { triangulation }\end{array}$ \\
\hline 2011 & $\begin{array}{l}\text { Newell and } \\
\text { Newell }\end{array}$ & $\begin{array}{l}\text { Problem analysis } \\
\text { procedures used in }\end{array}$ & Case study & $\begin{array}{l}\text { Not specified } \\
\text { a priori }\end{array}$ & 4 consultants & $\begin{array}{l}\text { Intercoder } \\
\text { agreement }\end{array}$ \\
\hline
\end{tabular}




\begin{tabular}{|c|c|c|c|c|c|c|}
\hline Year & Author(s) & Processes Studied & $\begin{array}{c}\text { Methodological } \\
\text { Approach }\end{array}$ & $\begin{array}{l}\text { Consultation } \\
\operatorname{Model}(\mathbf{s})\end{array}$ & Sample $(N$, roles $)$ & $\begin{array}{l}\text { Author- } \\
\text { Identified } \\
\text { Credibility } \\
\text { Features }\end{array}$ \\
\hline & & $\begin{array}{l}\text { simulated } \\
\text { consultation cases }\end{array}$ & & & & \\
\hline 2012 & Knotek & $\begin{array}{l}\text { Culturally } \\
\text { responsive } \\
\text { facilitation of } \\
\text { problem-solving } \\
\text { teams }\end{array}$ & $\begin{array}{c}\text { Ethnography } \\
\text { (Microethnography) }\end{array}$ & $\mathrm{IC} / \mathrm{CCC}$ & 2 consultants & $\begin{array}{c}\text { Data } \\
\text { triangulation; } \\
\text { member } \\
\text { checking; peer } \\
\text { debriefing }\end{array}$ \\
\hline 2012 & Newell & $\begin{array}{l}\text { Novice consultants' } \\
\text { competence in } 6 \\
\text { consultation } \\
\text { competency areas }\end{array}$ & $\begin{array}{l}\text { Case Study } \\
\text { (Collective) }\end{array}$ & $\begin{array}{l}\text { Not specified } \\
\text { a priori }\end{array}$ & 3 CITs & $\begin{array}{l}\text { Member } \\
\text { checking; } \\
\text { intercoder } \\
\text { agreement }\end{array}$ \\
\hline 2012 & Newman & $\begin{array}{l}\text { Supervision of } \\
\text { instructional } \\
\text { consultants during } \\
\text { consultation training }\end{array}$ & $\begin{array}{l}\text { Grounded Theory } \\
\text { (Constructivist) }\end{array}$ & $\mathrm{CCC}$ & 5 CITs & $\begin{array}{l}\text { Data } \\
\text { triangulation; } \\
\text { audit; } \\
\text { researcher } \\
\text { positionality; } \\
\text { memoing }\end{array}$ \\
\hline 2013 & DeNatale & $\begin{array}{l}\text { Characteristics of } \\
\text { consultation } \\
\text { relationship between } \\
\text { mental health } \\
\text { consultants and } \\
\text { program } \\
\text { administrators }\end{array}$ & $\begin{array}{l}\text { Grounded Theory } \\
\text { (Constructivist) }\end{array}$ & $\mathrm{MHC}$ & $\begin{array}{l}10 \text { consultants; } 15 \\
\text { administrator } \mathrm{c}- \\
\text { tees }\end{array}$ & $\begin{array}{l}\text { Member } \\
\text { checking; } \\
\text { replicable } \\
\text { coding; rich } \\
\text { description }\end{array}$ \\
\hline 2013 & $\begin{array}{l}\text { Massé, } \\
\text { Couture, } \\
\text { Levesque, }\end{array}$ & $\begin{array}{l}\text { Consultants', } \\
\text { consultees', and } \\
\text { administrators' }\end{array}$ & Mixed & $\mathrm{BC}$ and $\mathrm{MHC}$ & $\begin{array}{c}11 \text { consultants; } 42 \\
\text { teacher c-tees, } 8 \\
\text { administrators }\end{array}$ & $\begin{array}{l}\text { Consensus } \\
\text { coding }\end{array}$ \\
\hline
\end{tabular}




\begin{tabular}{|c|c|c|c|c|c|c|}
\hline Year & Author(s) & Processes Studied & $\begin{array}{c}\text { Methodological } \\
\text { Approach }\end{array}$ & $\begin{array}{l}\text { Consultation } \\
\text { Model(s) }\end{array}$ & Sample $(N$, roles $)$ & $\begin{array}{c}\text { Author- } \\
\text { Identified } \\
\text { Credibility } \\
\text { Features }\end{array}$ \\
\hline & \& Bégin & $\begin{array}{l}\text { perceptions of } \\
\text { individual and } \\
\text { group-based } \\
\text { consultation }\end{array}$ & & & & \\
\hline $2013 a$ & $\begin{array}{l}\text { Newell, } \\
\text { Newell, \& } \\
\text { Looser, }\end{array}$ & $\begin{array}{l}\text { Novice consultants' } \\
\text { approach to } \\
\text { multicultural issues } \\
\text { and obstacles } \\
\text { encountered during } \\
\text { multicultural } \\
\text { consultation }\end{array}$ & $\begin{array}{l}\text { Case Study } \\
\text { (Collective) }\end{array}$ & $\begin{array}{l}\text { Not specified } \\
\text { a priori }\end{array}$ & 4 CITs & $\begin{array}{c}\text { Data } \\
\text { triangulation; } \\
\text { member } \\
\text { checking; } \\
\text { intercoder } \\
\text { agreement }\end{array}$ \\
\hline $2013 b$ & $\begin{array}{l}\text { Newell, } \\
\text { Newell, \& } \\
\text { Looser }\end{array}$ & $\begin{array}{l}\text { Novice consultants' } \\
\text { attention to } \\
\text { multicultural issues }\end{array}$ & Case Study & $\mathrm{PS} / \mathrm{BC}$ & 5 CITs & $\begin{array}{l}\text { Member } \\
\text { checking; } \\
\text { intercoder } \\
\text { agreement }\end{array}$ \\
\hline 2014 & $\begin{array}{l}\text { Hazel, Pfaff, } \\
\text { Albanes, \& } \\
\text { Gallagher }\end{array}$ & $\begin{array}{l}\text { Influence of } \\
\text { multitiered } \\
\text { consultation on } \\
\text { implementation of } \\
\text { MTSS }\end{array}$ & Case Study & $\begin{array}{l}\text { PS with social } \\
\text { justice } \\
\text { emphasis }\end{array}$ & $\begin{array}{l}1 \text { neighborhood } \\
\text { high school }\end{array}$ & $\begin{array}{l}\text { Member } \\
\text { checking }\end{array}$ \\
\hline 2014 & $\begin{array}{l}\text { Newman, } \\
\text { Salmon, } \\
\text { Cavanaugh, } \\
\text { \& Schneider }\end{array}$ & IC in an RtI context & Mixed & IC & 23 consultants & $\begin{array}{c}\text { Data } \\
\text { triangulation; } \\
\text { researcher } \\
\text { debriefing }\end{array}$ \\
\hline
\end{tabular}


Note. ASD = autism spectrum disorder. $\mathrm{BC}=$ behavioral consultation. $\mathrm{CCC}=$ consultee-centered consultation. $\mathrm{CIT}=$ consultant in training. $\mathrm{EBI}=$ evidence-based intervention. $\mathrm{IC}=$ instructional consultation. $\mathrm{MHC}=$ Mental health consultation. $\mathrm{MTSS}=$ multi-tiered systems of support. OC = organizational consultation. PS = problem solving. RtI = response to intervention. SST $=$ student support team. To conserve space, the professions of consultants are not specified here. Most consultants were school psychologist participants; see narrative for the specific professions represented in this review. Full references provided in the Appendix. 
Table 2.

Initial Codes and Definitions

\begin{tabular}{|c|c|}
\hline Code & Definition \\
\hline $\begin{array}{l}\text { System } \\
\text { Challenges }\end{array}$ & $\begin{array}{l}\text { Aspects of the organizational context in which the consultation } \\
\text { takes place (e.g., school climate) that make consulting more } \\
\text { difficult }\end{array}$ \\
\hline $\begin{array}{l}\text { System } \\
\text { Facilitators or } \\
\text { Solutions }\end{array}$ & $\begin{array}{l}\text { Aspects of the organizational context in which the consultation } \\
\text { takes place (e.g., school climate) that enhance the capacity for } \\
\text { consultation }\end{array}$ \\
\hline $\begin{array}{l}\text { Contextual } \\
\text { Considerations }\end{array}$ & $\begin{array}{l}\text { How aspects of the organizational context are addressed by the } \\
\text { consultant or other parties to enhance the organizational capacity } \\
\text { for consultation }\end{array}$ \\
\hline $\begin{array}{l}\text { Cultural } \\
\text { Responsiveness }\end{array}$ & $\begin{array}{l}\text { Understanding and adapting to the needs of individuals (e.g., } \\
\text { students, adults) or the organizational context (e.g., school) }\end{array}$ \\
\hline $\begin{array}{l}\text { Family } \\
\text { Involvement }\end{array}$ & $\begin{array}{l}\text { Aspects of parents' and caregivers' participation in consultation } \\
\text { activities affecting consultation processes, or how family } \\
\text { involvement is addressed or encouraged by consultants, } \\
\text { consultees, and/or organizations }\end{array}$ \\
\hline $\begin{array}{l}\text { Consultation- } \\
\text { specific } \\
\text { Challenges }\end{array}$ & $\begin{array}{l}\text { Aspects of the consultation (e.g., relational dynamics between } \\
\text { consultant and consultee) that make consulting more difficult }\end{array}$ \\
\hline $\begin{array}{l}\text { Consultation- } \\
\text { specific } \\
\text { Facilitators or } \\
\text { Solutions }\end{array}$ & $\begin{array}{l}\text { Aspects of the consultation (e.g., relational dynamics between } \\
\text { consultant and consultee) that that enhance the capacity for } \\
\text { consultation }\end{array}$ \\
\hline $\begin{array}{l}\text { Training } \\
\text { Implications }\end{array}$ & $\begin{array}{l}\text { Implications of results for consultation training indicated in study } \\
\text { results or discussions }\end{array}$ \\
\hline $\begin{array}{l}\text { Research } \\
\text { Implications }\end{array}$ & $\begin{array}{l}\text { Coders' impression of how study findings speak to next priorities } \\
\text { for school consultation research }\end{array}$ \\
\hline
\end{tabular}


Table 3.

Evidence for Emergent Themes and Subthemes

\begin{tabular}{|c|c|}
\hline Theme & Subtheme (Studies where prominent; see Appendix) \\
\hline \multirow{4}{*}{$\begin{array}{l}\text { System-level factors matter for how } \\
\text { consultation proceeds }\end{array}$} & Time as a resource $(2,3,5,6,10,12,16,17,18,20,22,23,31,32,33,36)$ \\
\hline & $\begin{array}{l}\text { Understanding school culture and establishing clear expectations }(1,5,7,9,15 \text {, } \\
16,18,22,23,31,32,33)\end{array}$ \\
\hline & The "expert problem" $(1,3,9,12,18)$ \\
\hline & Administrator involvement $(6,7,10,16,21,33,38)$ \\
\hline \multirow[t]{2}{*}{ Establishing consultation coherence } & $\begin{array}{l}\text { Premature advice giving/rushing through problem solving stages contributes } \\
\text { to incoherence }(3,4,11,12,23,27,30,31,37)\end{array}$ \\
\hline & $\begin{array}{l}\text { Consultation structures, including systematic prioritizing, contribute to } \\
\text { coherence }(3,4,6,18,23,33,38)\end{array}$ \\
\hline \multirow{4}{*}{$\begin{array}{l}\text { Consultee voice, social-emotional support } \\
\text { and learning }\end{array}$} & Consultation as a "lifeline" $(2,3,12,17,34,36,37)$ \\
\hline & Consultee learning: Reflective practice $(3,5,15,17,20,34,37)$ \\
\hline & Consultee learning: Relevant content $(1,2,7,13,20,28,34)$ \\
\hline & Consultee voice $(6,7,9,10,14,16,18,20,21,23,33,34,36,37,38)$ \\
\hline
\end{tabular}


Consultation as ecologically oriented, culturally responsive, and are these distinct?
Ecological approach or lack of ecological approach $(2,4,9,14,15,16,18,19$, $25,27,29,30,32,34,38$ )

Cultural responsiveness or lack of cultural responsiveness: Consultants/consultees $(8,13,14,16,18,19,25,29,35)$

Cultural responsiveness or lack of cultural responsiveness: Innovations/systems $(16,22,32)$

Cultural responsiveness versus storytelling (NA)
Consultation training supports consultants' and teams' application of relational process skills
$(4,5,7,9,11,13,19,23,24,25,27,28,29,30,31,32,33,35)$

Note. NA = not applicable because it is a meta-theme across studies rather than represented in individual studies. 
Table 4.

\section{Next Research Priorities}

\begin{tabular}{|c|c|c|}
\hline $\begin{array}{l}\text { Theme and } \\
\text { Subthemes }\end{array}$ & $\begin{array}{l}\text { Subareas for Further } \\
\text { Research Exploration }\end{array}$ & Potential Research Questions \\
\hline \multirow{3}{*}{$\begin{array}{l}\text { System-level factors } \\
\text { matter for how } \\
\text { consultation proceeds } \\
\text { - Time as a } \\
\text { resource } \\
\text { - Understanding } \\
\text { school culture } \\
\text { and establishing } \\
\text { clear } \\
\text { expectations } \\
\text { - The "expert } \\
\text { problem" } \\
\text { - Administrator } \\
\text { involvement }\end{array}$} & $\begin{array}{l}\text { Creating/advocating for time } \\
\text { resources }\end{array}$ & $\begin{array}{l}\text { - What are ways to create time for consultation in schools? } \\
\text { - How do consultants best advocate for time to consult? } \\
\text { - How do consultants most effectively demonstrate to } \\
\text { - Whinistrators and consultees the value of consultation? } \\
\text { - } \text { - What are alternative approaches to CCC that require only brief } \\
\text { time in certain aspects of consultation?* }\end{array}$ \\
\hline & Entry and contracting & $\begin{array}{l}\text { - How much time should be devoted to system entry (i.e., } \\
\text { relationship development and understanding) prior to } \\
\text { establishing a contract?* } \\
\text { - How are schools similar or different to other organizations? } \\
\text { - What are the essential features of a consultative contract? } \\
\text { - How do individual consultation contracts differ from } \\
\text { organizational contracts? }\end{array}$ \\
\hline & The "expert problem" & $\begin{array}{l}\text { - What factors make teachers receptive to consultation?* } \\
\text { - How does collaboration at the pre-service level relate to } \\
\text { collaboration at the inservice level?* } \\
\text { - For whom is "the expert problem" a problem and how do they } \\
\text { articulate the problem? * }\end{array}$ \\
\hline
\end{tabular}


Administrator involvement

- What administrative characteristics and factors best support consultation implementation?

- What administrative characteristics and factors undermine the success of consultation?

\begin{tabular}{|c|c|c|}
\hline \multirow{2}{*}{$\begin{array}{l}\text { Establishing } \\
\text { consultation coherence } \\
\text { - } \\
\text { Premature } \\
\text { advice giving/ } \\
\text { rushing through } \\
\text { problem solving } \\
\text { stages } \\
\text { contributes to } \\
\text { incoherence } \\
\text { Consultation } \\
\text { structures, } \\
\text { including } \\
\text { systematic } \\
\text { prioritizing, } \\
\text { contribute to } \\
\text { coherence }\end{array}$} & Consultation structures & $\begin{array}{l}\text { - What structures are important for consultation coherence?* } \\
\text { - Are there differences in which structures contribute to } \\
\text { coherence in individual consultation versus team-based } \\
\text { consultation? } \\
\text { - What interpersonal factors contribute to premature advice } \\
\text { giving/inappropriate rushing through problem solving stages } \\
\text { during consultation?* } \\
\text { - How can advice giving/rushing to intervene best be } \\
\text { circumvented? }\end{array}$ \\
\hline & $\begin{array}{l}\text { Communication and } \\
\text { relationships }\end{array}$ & $\begin{array}{l}\text { - How do interpersonal factors, including communication skills, } \\
\text { contribute to coherent problem solving in individual and team- } \\
\text { based consultation?* } \\
\text { - How do interpersonal factors, including communication skills, } \\
\text { differ during individual versus team-based consultation? } \\
\text { - How might the influence of interpersonal factors vary during } \\
\text { different problem solving stages?* }\end{array}$ \\
\hline $\begin{array}{l}\text { Consultee voice, social- } \\
\text { emotional support, and } \\
\text { learning } \\
\text { - Consultation as } \\
\text { a "lifeline" } \\
\text { - Consultee } \\
\text { learning: }\end{array}$ & $\begin{array}{l}\text { Consultee benefits from } \\
\text { consultation }\end{array}$ & $\begin{array}{l}\text { - How do the knowledge/skills developed during individual or } \\
\text { team-based consultative problem solving generalize to a } \\
\text { consultee's work with students? } \\
\text { - What factors contribute to knowledge/skills generalization?* } \\
\text { - In what ways do consultees report that consultation benefitted } \\
\text { them?* } \\
\text { - What social-emotional supports do consultees report that }\end{array}$ \\
\hline
\end{tabular}


Reflective

practice

- Consultee

learning:

Relevant

content

- Consultee voice

consultation provides?*

Peer support groups

- What knowledge/skills are generalized into practice by consultees participating in relationally oriented peer consultation groups?

- What factors contribute to knowledge/skills generalization?*

- How do relationally oriented peer consultation groups that are facilitated by a consultant differ from those without a facilitator?

How consultees contribute to effective consultation
- What specialized expertise do teachers bring to consultation, and how can consultants capitalize on consultee knowledge?

- How do consultant conceptualizations of the problem and its prospective solution(s) develop alongside the consultee?

- What conditions contribute to the importance of consultee voice?*

- What factors contribute to and inhibit consultee voice in contemporary school settings (e.g., those with multi-tiered systems of support or MTSS)?*

- What kinds of consultant comments/questions promote consultee feelings of having voice and what reduce consultee voice?*

- What is the impact of consultee voice on consultation processes, outcomes, and social validity for consultees?

\section{Consultation as} ecologically oriented, culturally responsive, and are these distinct?

$$
\text { - Ecological }
$$

- How are ecologically oriented and culturally responsive alike and how are they different?*

- When does it make sense to focus consultative problem solving on individual student and family factors, and when might those distract from ecological problem solving (e.g., through 


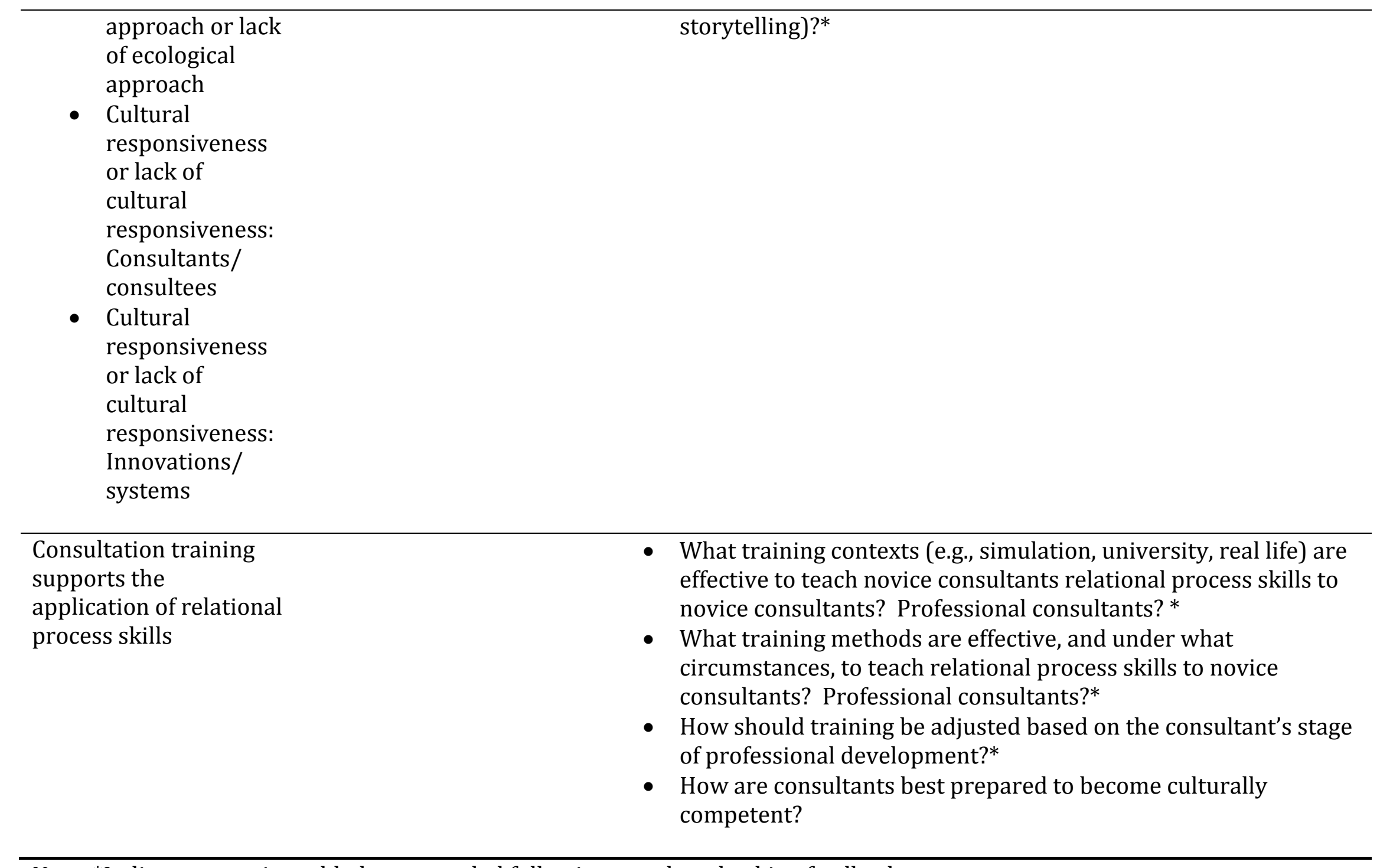

Note. *Indicates question added or reworded following member checking feedback. 
Figure 1. Search and retrieval of the metasynthesis sample

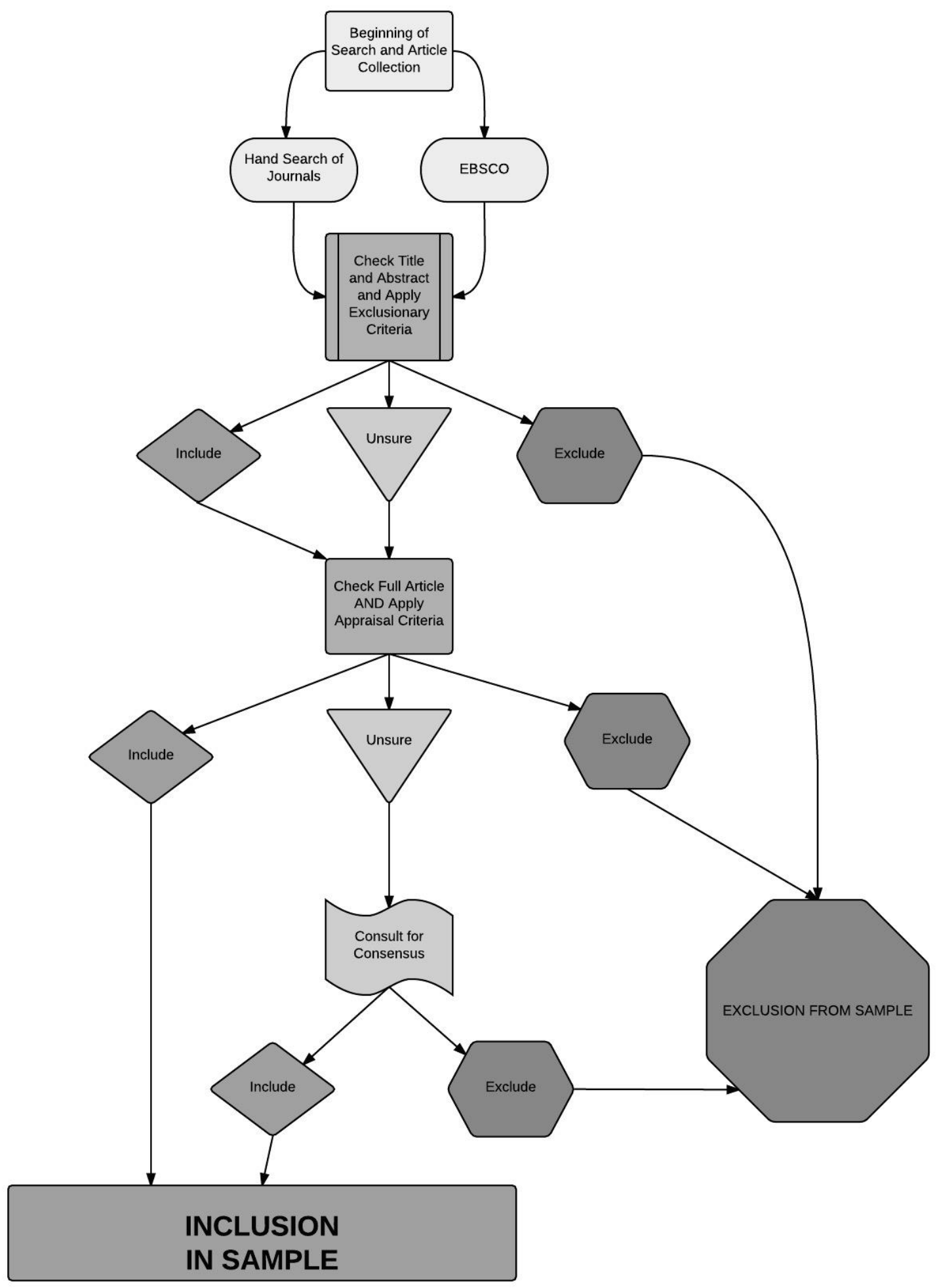




\section{References}

American Psychological Association (2006). Evidence-based practice in psychology. American Psychologist, 61, 271-285. http://dx.doi.org/10.1037/0003066X.61.4.271

Charmaz, K. (2014). Constructing grounded theory (2 ${ }^{\text {nd }}$ ed.). London: Sage Cooper, H.M. (2010). Research synthesis and meta-analysis: A step-by-step approach. Thousand Oaks, CA: Sage.

Creswell, J.W. (2013). Qualitative inquiry and research design: Choosing among five approaches ( $3^{\text {rd }}$ ed.). Thousand Oaks, CA: Sage.

Eisner, E. W. (1997). The enlightened eye: Qualitative inquiry and the enhancement of educational practice (2/E). Upper Saddle River, NJ: Pearson.

Erchul, W. P., \& Sheridan, S. M. (2014). Overview: The state of scientific research in school consultation. In W. P. Erchul \& S. M. Sheridan (Eds.), Handbook of research in school consultation (2nd ed.) (pp. 3-17). New York, NY: Routledge.

Erwin, E. J., Brotherson, M. J., \& Summers, J. A. (2011). Understanding qualitative metasynthesis: Issues and opportunities in early childhood intervention research. Journal of Early Intervention, 33, 186-200.

Glaser, B. G. \& Strauss, A. L. (1967). The discovery of grounded theory: Strategies for qualitative research. Chicago: Aldine Publishing Company

Glaser, B. G., \& Strauss, A. L. (1971). Status passage. Chicago: Aldine.

Henning-Stout, M. (1993). Theoretical and empirical bases of consultation. In J. E. Zins, T. R. Kratochwill \& S. N. Elliott (Eds.), Handbook of consultation services for children (pp. 15-45). San Francisco, CA: Jossey-Bass. 
Hylander, I. (2003). Toward a grounded theory of the conceptual change process in consultee-centered consultation. Journal of Educational and Psychological Consultation, 14, 263-280.

Ingraham, C. L. (2000). Consultation through a multicultural lens: Multicultural and cross-cultural consultation in schools. School Psychology Review, 29, 320-343.

Ingraham, C. L. (2003). Multicultural consultee-centered consultation: When novice consultants explore cultural hypotheses with experienced teacher consultees. Journal of Educational and Psychological Consultation, 14(3 \& 4), 329-362.

Ingraham, C. L. (2014). Studying multicultural aspects of consultation. In W. P. Erchul \& S. M. Sheridan (Eds.), Handbook of research in school consultation (2nd ed.) (pp. 323-348). New York, NY: Routledge.

Ingraham, C.L. \& Meyers, J. (2000). Multicultural and cross-cultural consultation in schools [Mini-series]. School Psychology Review, 29(3).

Knotek, S. E. (2003b). Making sense of jargon during consultation: Understanding consultees' social language to effect change in student study teams. Journal of Educational and Psychological Consultation, 14, 181-207.

Knotek, S. E., \& Hylander, I. (2014). Research issues in mental health consultation and consultee-centered approaches. In W. P. Erchul \& S. M. Sheridan (Eds.), Handbook of research in school consultation: Empirical foundations for the field (2nd ed.) (pp. 153-179). New York: Routledge. 
Knotek, S.E. \& Sandoval, J. (2003a). Consultee centered consultation as a constructivistic process: Directions in theory and research [Special double issue]. Journal of Educational and Psychological Consultation, 14 (3 \& 4).

Knotek, S.E. \& Sandoval, J. (2003b). Introduction to the special issue: Consultee centered consultation as a constructivistic process. [Special issue]. Journal of Educational and Psychological Consultation, 14, 243-250.

doi:10.1080/10474412.2003.9669487

Kratochwill, T. R. (2007). Preparing psychologists for evidence-based school practice: Lessons learned and challenges ahead. American Psychologist, 62(8), 829-843. doi:10.1037/0003-066X.62.8.829

Lincoln, Y.S., \& Guba, E. G. (2013). The constructivist credo. Walnut Creek, CA: Left Coast Press.

Lambert, N. M. (2004). Consultee-centered consultation: An international perspective on goals, process, and theory. In N. M. Lambert, I. Hylander and J. Sandoval (Eds.), Consultee-centered consultation: Improving the quality of professional services in schools and community organizations (pp. 3-20). Mahwah, NJ: Lawrence Erlbaum.

Ma, N., Roberts, R., Winefield, H., \& Furber, G. (2015). Utility of qualitative metasynthesis: Advancing knowledge on the wellbeing and needs of siblings of children with mental health problems. Qualitative Psychology, 2(1), 3-28. http://dx.doi.org/10.1037/qup0000018

Major, C. H., \& Savin-Baden, M. (2010). An introduction to qualitative research synthesis: Managing the information explosion in social science research. New 
York: Routledge.

Meyers, J. (1973). A consultation model for school psychological services. Journal of School Psychology, 11, 5-15. doi:10.1016/0022-4405(73)90003-4

Meyers, J., Truscott, S. D., Meyers, A. B., Varjas, K., \& Kim, S. Y. (2014). Qualitative and mixed methods designs in consultation research. In W. P. Erchul \& S. M. Sheridan (Eds.), Handbook of research in school consultation: Empirical foundations for the field (2 $2^{\text {nd }}$ ed.) (pp. 103-137). New York: Routledge.

Noblit, G. W., \& Hare, R. D. (1988). Meta-Ethnography: Synthesizing qualitative studies. Newbury Park, CA: Sage Publications.

Reddy, L. A., Barboza-Whitehead, S., Files, T., \& Rubel, E. (2000). Clinical focus of consultation outcome research with children and adolescents. Special Services in the Schools, 16, 1-22.

Rice, M. J. (2008). Evidence-based practice in psychiatric and mental health nursing: Qualitative meta-synthesis. Journal of the American Psychiatric Nurses Association, 14, 382-385. doi:10.1177/1078390308326661.

Rosenfield, S.A., Gravois, T.A., \& Silva, A.E. (2014). Bringing instructional consultation to scale: Research and development of IC and IC teams. In W. P. Erchul \& S. M. Sheridan (Ed.), Handbook of research in school consultation (2nd ed.), (pp. 248-275). New York: Routledge.

Saldaña, J. (2013). The coding manual for qualitative researchers $\left(2^{\text {nd }}\right.$ ed.). London: Sage Sandelowski, M. (2012). Metasynthesis of qualitative research. In H. Cooper (Ed.), APA handbook of research methods in psychology: Volume 2. Research designs. (pp. 19-36). Washington, DC: American Psychological Association. 
Sandelowski, M., \& Barroso, J. (2007). Handbook for synthesizing qualitative research. New York: Springer.

Schlosser, L. Z., Dewey, J. H., \& Hill, C. E. (2012). Auditing. In C. E. Hill (Ed.). Consensual qualitative research: A practical resource for investigating social science phenomena (pp. 135-144). Washington, DC: American Psychological Association.

Scruggs, T. E., Mastropieri, M. A., \& McDuffie, K. A. (2007). Co-teaching in inclusive classrooms: A metasynthesis of qualitative research. Exceptional Children, 73, 392-416.

Sheridan, S. M., \& Gutkin, T. B. (2000). The ecology of school psychology: Examining and changing our paradigm for the 21st century. School Psychology Review, 29, 485-502.

Sheridan, S. M., Welch, M., \& Orme, S. F. (1996). Is consultation effective? A review of outcome research. Remedial and Special Education, 17, 341-354.

Strauss, A., \& Corbin, J. (1998). Basics of qualitative research: Techniques and procedures for developing grounded theory ( $2^{\text {nd }}$ ed.). Thousand Oaks, CA: Sage 


\title{
Appendix
}

\author{
Reference List of Articles Included in Final Sample
}

1. Al Otalba, S. Hosp, J., Smartt, S. \& Dole., J. A. (2008). The challenging role of a reading coach, a cautionary tale. Journal of Educational and Psychological Consultation, 18, 124-155. doi: 10.1080/10474410802022423

2. Athanasiou, M. S., Geil, M., Hazel, C. E., \& Copeland, E. P. (2002). A look inside school-based consultation: A qualitative study of the beliefs and practices of school psychologists and teachers. School Psychology Quarterly, 17, 258-298. http://dx.doi.org/10.1521/scpq.17.3.258.20884

3. Babinski, L. M., \& Rogers, D. L. (1998). Supporting new teachers through consultee centered consultation. Journal of Educational and Psychological Consultation, 9, 285-308. doi:10.1207/s1532768xjepc0904

4. Benn, A., Jones, G., \& Rosenfield, S. (2008). Analysis of instructional consultants' questions and alternatives to questions during the problem identification interview. Journal of Educational and Psychological Consultation, 19, 54-80. doi: 10.1080/10474410701864115

5. DeNatale, L. M. (2013). Intersubjective experience of the infant and early childhood mental health consultant-program administrator consultee relationship. Infant Mental Health Journal, 34, 470-482. doi:10.1002/imhj.21403

6. Etscheidt, S., \& Knesting, K. (2007). A qualitative analysis of factors influencing the interpersonal dynamics of a prereferral team. School Psychology Quarterly, 22, 264-288. doi:10.1037/1045-3830.22.2.264

7. Frankel, E. B. (2006). The knowledge, skills and personal qualities of early childhood resource consultants as agents of change. Exceptionality Education Canada, 16, 35-58. doi: 10.1080/10901027.2014.968300

8. Goldstein, B. S. C., \& Harris, K. C. (2000). Consultant practices in two heterogeneous Latino Schools. School Psychology Review, 29, 368-377.

9. Hasselbusch, A. \& Penman, M. (2008). Working together: an occupational therapy perspective on collaborative consultation. Kairaranga, 9, 24-31. Retrieved from http://eric.ed.gov/?id=EJ908172

10. Henning-Stout, M. (1999). Learning consultation: an ethnographic analysis. Journal of School Psychology, 37, 73-98. http://dx.doi.org.proxy.cc.uic.edu/10.1016/S0022-4405(98)00026-0 
11. Henning-Stout, M. \& Bonner, M. (1996). Affiliation and isolation in the professional lives of school psychologists. Journal of Educational and Psychological Consultation, 7, 41-60. doi:10.1207/s1532768xjepc0701_4

12. Hazel, C. E., Pfaff, K., Albanes, J. and Gallagher, J. (2014). Multi-level consultation with an urban school district to promote 9th grade supports for on-time graduation. Psychology in the Schools, 51, 395-420. doi:10.1002/pits.21752

13. Ingraham, C. L. (2003). Multicultural consultee-centered consultation: When novice consultants explore cultural hypotheses with experienced teacher consultees. Journal of Educational and Psychological Consultation, 14, 329-362. doi: 10.1080/10474412.2003.9669492

14. Knotek, S. E. (2003a). Bias in problem solving and the social process of student study teams a qualitative investigation. Journal of Special Education, 37, 2-14. doi:10.1177/00224669030370010101

15. Knotek, S. E. (2003b). Making sense of jargon during consultation: understanding consultees' social language to effect change in student study teams. Journal of Educational and Psychological Consultation, 14, 181-207. doi:10.1207/s1532768xjepc1402_5

16. Knotek, S. E. (2012). Utilizing culturally responsive consultation to support innovation implementation in a rural school. Consulting Psychology Journal: Practice and Research, 64, 46-62. doi:10.1037/a0027993

17. Knotek S. E., Babinksi L. M., \& Rogers D. L. (2002). Consultation in new teacher groups: school psychologists facilitating collaboration among new teachers. California School Psychologist, 7, 39-50. doi:10.1007/BF03340888

18. Knotek, S. E., Rosenfield, S., Gravois, T. A., \& Babinski, L. (2003). The process of fostering consultee development during instructional consultation. Journal of Educational and Psychological Consultation, 14, 303-328. doi:10.1080/10474412.2003.9669491

19. Lopez, E. C. (2000). Conducting Instructional Consultation through Interpreters. School Psychology Review, 29, 378-88.

20. Masse, L., Couture, C., Levesque, V., \& Begin, J. (2013). Impact of school consulting programme aimed at helping teachers integrate students with behavioural difficulties into secondary school: actors' point of view. Emotional and Behavioural Difficulties, 18, 327-343. doi:10.1080/13632752.2013.775719

21. McDougal, J., Nastasi, B., \& Chafouleas, S. (2005). Bringing research into practice to intervene with young behaviorally challenging students in public school 
settings: Evaluation of the behavioral consultation team (BCT) project. Psychology in the Schools, 42, 537-551. doi:10.1002/pits.20090

22. Meyers, B. (2002). The contract negotiation stage of a school-based, crosscultural organizational consultation: A case study. Journal of Educational and Psychological Consultation, 13, 151-183. doi:10.1207/S1532768XJEPC1303_02

23. Meyers, B., Valentino, C. T., Meyers, J., Boretti, M, \& Brent, D. (1996). Implementing prereferral intervention teams as an approach to school-based consultation in an urban school system. Journal of Educational and Psychological Consultation, 7, 119-149. doi:10.1207/s1532768xjepc0702_2

24. Newell, M. L. (2010a). Exploring the use of computer simulation to evaluate the implementation of problem-solving consultation. Journal of Educational and Psychological Consultation, 20, 228-255. doi:10.1080/10474412.2010.500511

25. Newell, M. L. (2010b). The implementation of problem-solving consultation: An analysis of problem conceptualization in a multiracial context. Journal of Educational and Psychological Consultation, 20, 83-105. doi:10.1080/10474411003785529

26. Newell, M. L. (2012). Transforming knowledge to skill: Evaluating the consultation competence of novice school-based consultants. Consulting Psychology Journal: Practice and Research, 64, 8-28. doi:10.1037/a0027741

27. Newell, M. L. \& Newell, T. S. (2011). Problem analysis: examining the selection and evaluation of data during problem-solving consultation. Psychology in the Schools, 48, 943-957. doi:10.1002/pits.20606

28. Newell, M. L., Newell, T. S., \& Looser, J. (2013a). A competency-based assessment of school-based consultants' implementation of consultation. Training and Education in Professional Psychology, 7, 235-245. doi: 10.1037/a0033067

29. Newell, M. L., Newell, T. S., \& Looser, J. (2013b). Examining how novice consultants address cultural factors during consultation: illustration of a computer simulated case-study method. Consulting Psychology Journal: Practice and Research, 65, 74-86. doi:10.1037/a0032598

30. Newman, D. S. (2012). A grounded theory study of supervision of preservice consultation training. Journal of Educational and Psychological Consultation, 22, 247-279. doi:10.1080/10474412.2012.706127

31. Newman, D. S., Salmon, D., Cavanaugh, K., Schneider M. F. (2014). The consulting role in a response-to-intervention context: an exploratory study of instructional consultation. Journal of Applied School Psychology, 30, 278-304. 
doi:10.1080/15377903.2014.924456

32. Rubinson, F. (2012). Lessons learned from implementing problem-solving teams in urban high schools. Journal of Educational and Psychological Consultation, 13, 185-217. doi:10.1207/S1532768XJEPC1303_03

33. Slonski-Fowler, K. E., \& Truscott, S. D. (2004). General education teachers' perceptions of the prereferral intervention team process. Journal of Educational and Psychological Consultation, 15, 1-39. doi:10.1207/s1532768xjepc1501_1

34. Summers, S. J.; Funk, K.; Twombly, E.; Waddell, M.; \& Squires, J. (2007). The explication of a mentor model, videotaping, and reflective consultation in support of infant mental health. Infant Mental Health Journal, 28, 216-236. doi:10.1002/imhj.20130

35. Tarver Behring, S., Cabello, B., Kushida, D., \& Murguia, A. (2000). Cultural modifications to current school-based consultation approaches reported by culturally diverse beginning consultants. School Psychology Review, 29, 354-67.

36. Truscott, D. M. and Truscott, S. D. (2004). A professional development model for the positive practice of school-based reading consultation. Psychology in the Schools, 41, 51-65. doi:10.1037/a0027997

37. Webster, L., Knotek, S. E., Babinski, L. M., Rogers, D. L., \& Barnet, M. M. (2003). Mediation of consultee's conceptual development in new teacher groups: Using questions to improve coherency. Journal of Educational and Psychological Consultation, 14, 281-301. doi:10.1080/10474412.2003.9669490

38. Young, H. L., Gaughan, E. (2010). A multiple method longitudinal investigation of pre-referral intervention team functioning: Four years in rural schools. Journal of Educational \& Psychological Consultation, 20, 106-138.

doi:10.1080/10474411003785438 